\title{
Petrography, geochemistry and geochronology of San Jorge porphyry Cu-Au deposit, Mendoza, Argentina. Constraints for the timing of magmatism and associated mineralization
}

D.O.I.: https://doi.org/10.30550/j.agl/2018.30.1/1

\author{
Mirta M. GARRIDO ${ }^{1}$, Laura E. GRECCO ${ }^{2}$, María V. GONZALEZ ${ }^{1}$, \\ Cecilia M. PAVON PIVETTA ${ }^{1,2}$ \\ 1 Departamento de Geología. Universidad Nacional del Sur (UNS). Bahía Blanca. Argentina. \\ Correo electrónico: mgarrido@criba.edu.ar, violeta.gonzalez@uns.edu.ar, cecilia.pavon@uns.edu.ar \\ 2 Instituto Geológico del Sur (INGEOSUR). Departamento de Geología (UNS). Bahía Blanca. Argentina. \\ Correo electrónico: mlgrecco@criba.edu.ar
}

\begin{abstract}
> Abstract - The San Jorge porphyry Cu-Au deposit, Argentina, integrates the Paleozoic to Early Jurassic metallogenic belt recognized in the Southern Andes. San Jorge is currently the only deposit considered economically viable due to its supergene enrichment. Previous studies have reported Middle to Upper Permian ages (257-270 Ma) for the intrusion-mineralization processes. Granite porphyry, two granodiorite porphyries (G1 and G2) and an alkali-feldspar granite dike were recognized. These granites intrude sedimentary rocks (Yalguaráz Formation) that hosts the main mineralization. Two tourmaline alteration events occurred prior to the potassic episode. They are overprinted by phyllic alteration that has an elongated shape with potassic mineralized cores. The mineralization is linked to the potassic alteration in the sedimentary sequence and in the granite porphyry that has the highest Cu contents (1\% to $3 \%$ ). The phyllic alteration has pyrrhotite, arsenopyrite and minor chalcopyrite. Digenite, chalcocite and covellite appear in the supergene; malachite and brochantite in the oxide; and goethite, hematite and jarosite in gossan zones.

The granitic porphyry, granodiorite porphyries G1 and two potassic alteration biotites are of Early Permian age. This event produces the potassic alteration and mineralization and is $15 \mathrm{Ma}$ older than the ages determined by other authors. The granodiorite porphyry G2 and the alkali feldspar granite dike are Upper Permian in age. The results suggest that the evolution of the western margin of Gondwana began in late Carboniferous and continued during the Permian period. In this Paleozoic to early Jurassic metallogenic belt, La Voluntad Cu-Mo porphyry is the oldest deposit (early Pennsylvanian, Garrido et al. 2008). Mineralized and no mineralized San Jorge granites (Early Permian-Late Permian) integrate the intrusive event of the Choiyoi Group.
\end{abstract}

Keywords: San Jorge copper-gold deposit-petrography-geochemistry- ${ }^{40} \mathrm{Ar} /{ }^{39} \mathrm{Ar}$ and $\mathrm{U}-\mathrm{Pb}$ geochronology.

Resumen - "Petrografía, geoquímica y geocronología del pórfido Cu-Au San Jorge, Mendoza, Argentina. Límites para el magmatismo y la mineralización asociada". El depósito de pórfido Cu-Au de San Jorge, Argentina, integra el cinturón metalogénico del Paleozoico

\footnotetext{
> Ref. bibliográfica: Garrido, M. M., Grecco, L. E., González, M. V. y Pavón Pivetta, C. M. (2018). Petrography, geochemistry and geochronology of San Jorge porphyry Cu-Au deposit, Mendoza, Argentina. Constraints for the timing of magmatism and associated mineralization. Acta geológica lilloana 30 (1): 1-22
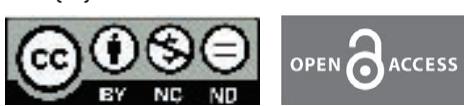

Recibido: 11/11/17 - Aceptado: 27/03/18

> URL de la revista: http://actageologica.lillo.org.ar

- Algunos derechos reservados. Esta obra está bajo una Licencia Creative Commons Atribución - No Comercial - Sin Obra Derivada 4.0 Internacional.
} 
M. M. Garrido et al.: Petrography, geochemistry and geochronology of San Jorge porphyry...

al Jurásico Temprano, reconocido en los Andes del Sur. San Jorge es actualmente el único depósito considerado económicamente viable debido a su enriquecimiento supergénico. Estudios previos dieron edades del Pérmico Medio a Superior (257-270 Ma) para los procesos de intrusión-mineralización. Se reconocieron pórfidos de granito, dos pórfidos de granodiorita (G1 y G2) y un dique de granito alcali-feldespático. Estos granitos intruyen rocas sedimentarias (Formación Yalguaráz) que alberga la principal mineralización. Dos eventos de turmalinización ocurrieron previos al episodio potásico. Están sobreimpuestos por una alteración fílica que tiene una forma elongada con núcleos mineralizados potásicos. La mineralización está ligada a la alteración potásica en la secuencia sedimentaria y en el pórfido de granito que tiene los mayores contenidos de Cu [1\% a 3\%]. La alteración fílica contiene pirrotina, arsenopirita y menor calcopirita. Digenita, calcosina y covelina aparecen en la zona supergénica; malaquita y brochantita en la de óxidos; y goethita, hematita y jarosita en las zonas gossan. El pórfido granítico, el pórfido de granodiorita G1 y dos biotitas de alteración potásica son de edad Pérmico inferior. Este evento produce alteración potásica y mineralización y tiene $15 \mathrm{Ma}$ más que las edades determinadas por otros autores. El pórfido de granodiorita G2 y el dique de granito álcali-feldespático son de edad Pérmico superior. Se propone un mínimo de 2 Ma de edad para la duración del sistema hidrotermal.

Los resultados sugieren que la evolución del margen occidental de Gondwana comenzó a finales del Carbonífero y continuó durante el período Pérmico. En este cinturón metalogénico del Paleozoico al Jurásico Temprano, el pórfido La Voluntad Cu-Mo es el depósito más antiguo (Pensilvaniano temprano, Garrido et al., 2008). Los granitos mineralizados y no mineralizados de San Jorge (Pérmico Temprano-Pérmico Superior) integran el evento intrusivo del Grupo Choiyoi.

Palabras clave: Depósito de Cu-Au San Jorge, petrografía, geoquímica, geocronología de ${ }^{40} \mathrm{Ar} /{ }^{39} \mathrm{Ar}$ y U-Pb.

\section{INTRODUCTION}

Porphyry copper deposits of similar age from the Andes in western South America have been grouped into a series of metallogenic belts. These NS belts are a few $\mathrm{km}$ wide and several $\mathrm{km}$ long and occur parallel to the Pacific margin. The San Jorge porphyry Cu-Au deposit, Argentina, is one of 13 porphyry $\mathrm{Cu}$ systems in the Paleozoic to Early Jurassic metallogenic belt (Fig. 1) recognized so far in the Southern Andes (Camus 2003; Sillitoe and Perelló 2005). San Jorge is currently the only porphyry $\mathrm{Cu}-\mathrm{Au}$ deposit in the Paleozoic Belt considered economically viable. Resources are estimated at $194.5 \mathrm{Mt}$ with $0.48 \% \mathrm{Cu}$, and $0.21 \mathrm{~g} / \mathrm{t}$ Au with a cutoff grade of $0.3 \% \mathrm{Cu}$ (Compañía Minera San Jorge-Coro Mining Corporation 2008). The supergene enrichment gives an economic possibility horizon to this deposit.

The purpose of this paper is to provide new geological information on the deposit and to better constrain the age of the San Jorge porphyry system using more reliable and robust isotopic systems.
The new geological information enables a detailed petrologic-geochemical study on the magmatism linked to the mineralization in an attempt to understand its tectonic formation environment. The granite porphyry and alkali feldspar dike rocks analysed in this work are comparable to those described by Williams et al. (1999) as granodiorite porphyry and the andesitic porphyry dike respectively. Here we use U-Pb zircon dating to determine the age of crystallization of intrusive bodies and a precise $40 \mathrm{Ar} / 39 \mathrm{Ar}$ technique on magmatic and hydrothermal biotite to better estimate the duration of the magmatic-hydrothermal process. Previous geochronological studies on the deposit have reported Middle to Upper Permian ages. A magmatic biotite from a granodiorite stock yielded a K-Ar age of $270 \pm 4$ Ma (Sillitoe 1977), whereas a hydrothermal biotite from a porphyritic andesite dike was dated using the K-Ar method at 263 \pm 6 Ma. Additionally, sericite from a quartzite sample yielded a K-Ar age of $257 \pm 5$ Ma (Williams et al. 1999). 


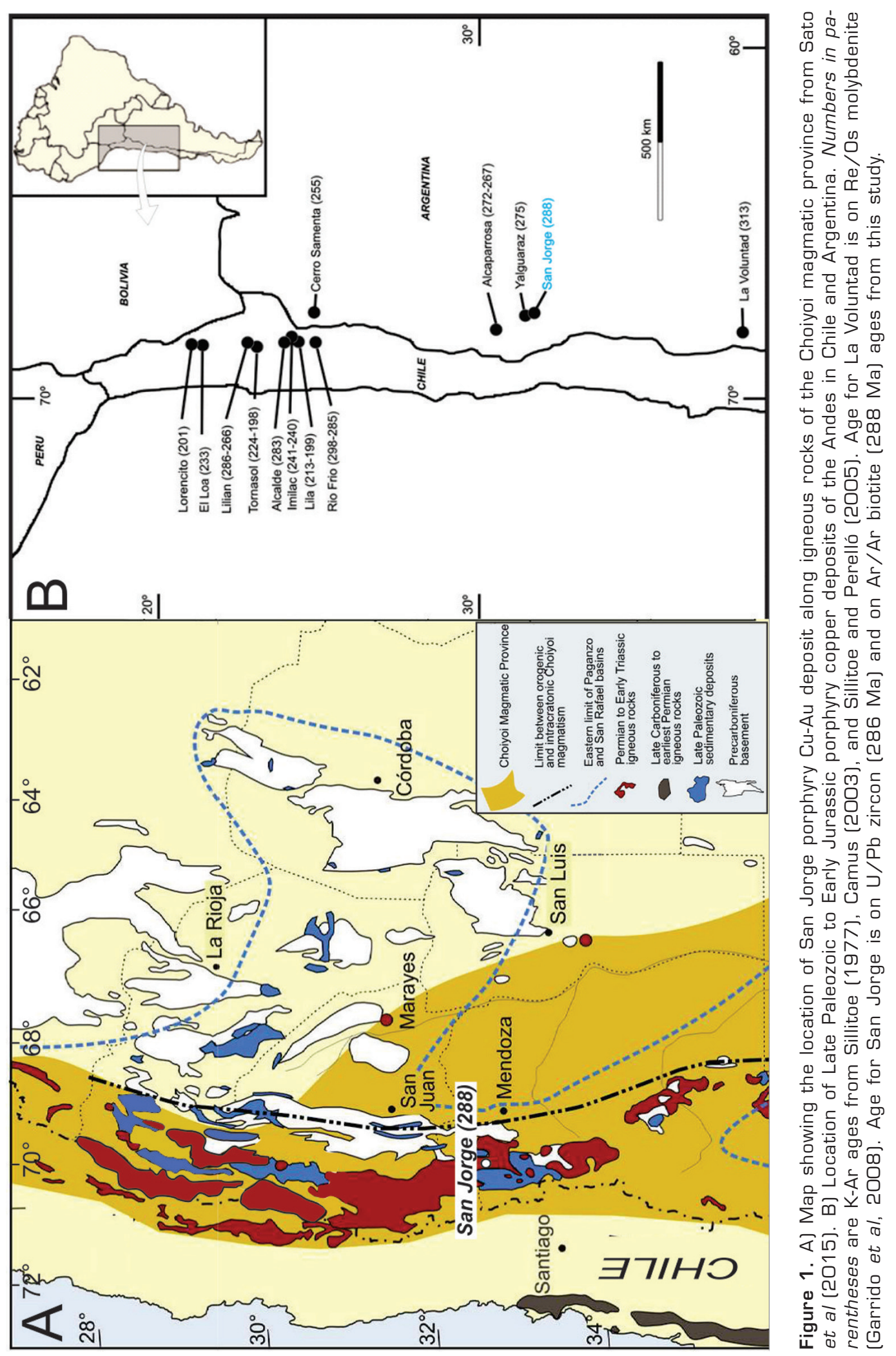




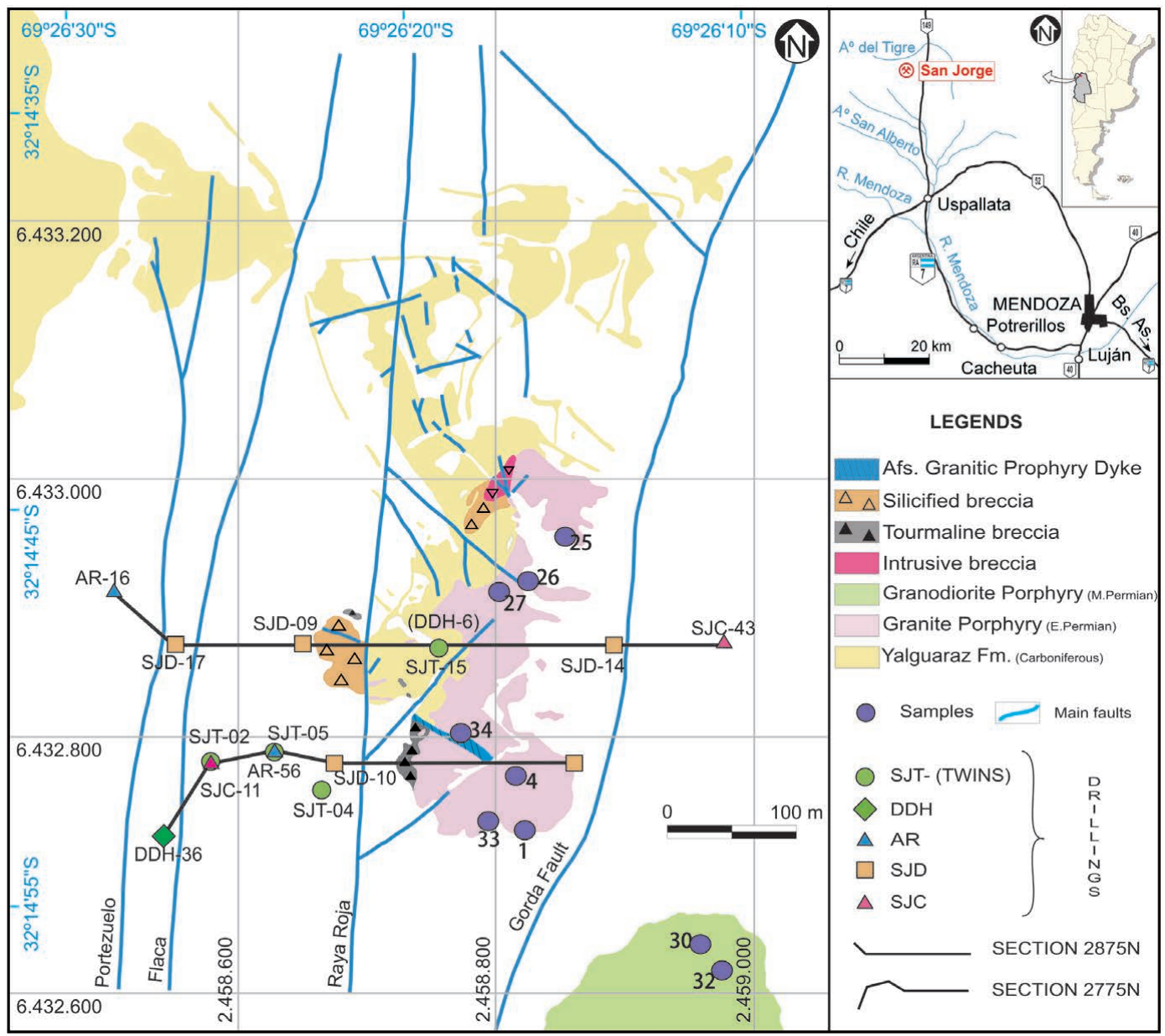

Figure 2. Geological map showing the location of the San Jorge porphyry copper deposit. Modified from Williams (1999) and Compañía Minera San Jorge SA (2008).

The results contribute to understanding the Andean Paleozoic porphyry systems and provide insights into the evolution of the western margin of Gondwana during the Permian.

\section{GEOLOGICAL SETTING}

The San Jorge deposit (32 $\left.10^{\prime} \mathrm{S}-6^{\circ} 27^{\prime} \mathrm{W}\right)$ is located in the Uspallata valley between the eastern foothills of Cordillera Frontal and Precordillera geologic provinces, at approximately $100 \mathrm{~km}$ WNW of Mendoza city, Argentina (Fig. 2).

The copper deposit is hosted by Carboniferous clastic rocks and Permian intrusions within the Permo-Triassic belt that stretches along the border between Chile and Argentina (Camus, 1998; Mpodozis and Ramos, 1989; Fig. 1).

The geology, in the deposit area is integrated by Carboniferous sediments of the Yalguaráz Formation (Amos and Rolleri 1965). The sequence has mainly red and grey subarkosic sandstones interbedded with several layers, from $20 \mathrm{~cm}$ to $1.5 \mathrm{~m}$, of conglomerates and shales. Structurally it is homoclinal with a strike from $0^{\circ}$ to $\mathrm{N} 35^{\circ} \mathrm{W}$ and a dipping of $10^{\circ}-45^{\circ} \mathrm{W}$. They lie unconformably over Ciénaga del Medio Formation basement formed by Devonian marine greywackes , siltstones and shales (Amos and Marchese 1965). A Permian granodiorite body (K-Ar 
biotite age of $270 \pm 4 \mathrm{Ma}$, Sillitoe 1977) intruded the Yalguaráz sedimentary sequence and outcrops in the southeastern edge of this area. An andesitic dike crosscuts this body in the southern part of the deposit and is considered post-Permian in age. Several breccia types have been recognized in the deposit, i.e. igneous, silicified and tourmaline breccias. The main fault structures such as the Gorda, Flaca, Raya Roja, and Portezuela have NS and N-NE strikes (Fig. 2).

Ignimbrites and andesites from the Permo-Triassic Choiyoi Group overlie the Yalguaráz Formation (Llambías 1999). A significant amount of alluvial deposits were produced during the Tertiary due to the rapid Andean uplift of the Cordillera Frontal and the Precordillera which filled the Uspallata-Calingasta-Iglesia Graben.

The main structural system has an N-NNE orientation and is parallel to the Uspallata graben, whereas secondary structures show NNW, NW, NE, and EW directions (Compañía Minera San Jorge S.A., internal report 2008).

\section{ANALYTICAL METHODS}

Thirty nine samples were collected from the less altered granitic outcrops and twelve samples along the drill cores SJT4 (Fig.4a) and SJT15 (Fig.4b) also shown in Fig. 2. All samples were affected by a pervasive meteoric alteration that obscures and obliterate the primary features. Outcrop samples 1 , $4,25,26,27$, and 33 correspond to granite porphyry. Samples 30 and 32 are from granodiorite porphyry. Sample 34 comes from an alkali feldspar granite dike.

The geochemical investigation was carried out by analysing 12 samples for major and trace elements of granitic rocks. The analyses were realized by ICP-MS at ACME, LF202 total whole rock characterization (Canada). International geostandards were used for calibration. Major elements were not used for igneous rock classification schemes because the rocks present supergene and hydrothermal alteration that modify their chemical compositions; only immobile trace elements were used for tectonic setting discrimination (Table 1).

The geochronological studies were done on three samples using $40 \mathrm{Ar} / 39 \mathrm{Ar}$ dating and three samples with U-Pb methods. Drill core samples from SJT15 at $112.4 \mathrm{~m}$ and SJT4 at $57.10 \mathrm{~m}$ depths were dated with $40 \mathrm{Ar} / 39 \mathrm{Ar}$ measurements. For the first drill core, a magmatic biotite from granodiorite porphyry and a hydrothermal biotite from a veinlet that crosscuts this rock were dated. For the second drill core a pervasive hydrothermal biotite from subarkosic sandstone was selected. Sample locations were plotted on the geologic map (Fig. 2), and their description is summarized in Table 2.

The rock samples were crushed in a ring mill, washed in distilled water and ethanol, and sieved when dry to $-40+60$ mesh. Appropriate mineral grains were picked out of the bulk fraction. Mineral separates were wrapped in aluminium foil and stacked in an irradiation capsule with similar-aged samples and neutron flux monitors (Fish Canyon Tuff sanidine (FCs), 28.03 Ma (Renne et al. 1998). The samples were irradiated at the McMaster Nuclear Reactor in Hamilton, Ontario, for $45 \mathrm{MWH}$, with a neutron flux of approximately $6 \times 1013$ neutrons/cm²/s. Analyses $(n=30)$ of 10 neutron flux monitor positions produced errors of $<0.5 \%$ in the $J$ value. The samples were analysed at the Noble Gas Laboratory, Pacific Centre for Isotopic and Geochemical Research, University of British Columbia, Vancouver, BC, Canada. The mineral separates were stepheated at incrementally higher powers in the defocused beam of a 10W CO2 laser (New Wave Research MIR10) until fused. The gas evolved from each step was analysed by a VG5400 mass spectrometer equipped with an ion-counting electron multiplier. All measurements were corrected for total system blank, mass spectrometer sensitivity, mass discrimination, radioactive decay during and subsequent to irradiation, as well as interfering Ar from atmospheric contamination and the irradiation of $\mathrm{Ca}, \mathrm{Cl}$ and $\mathrm{K}$ (isotope production ratios: $(40 \mathrm{Ar} / 39 \mathrm{Ar}) \mathrm{K}=0.0302 \pm 0.00006$, (37 Ar/39Ar) Ca $=1416.4 \pm 0.5,(36 \mathrm{Ar}$ ) 
Table 1. Chemical analyses of samples from San Jorge porphyry copper deposit (SJPD). Samples 1,4, 25, 26 and 27: granite porphyry; samples 30, 32 and 33: granodiorite porphyry ( G2); granodiorite porphyry samples [G1) from drill cores SJT15-101m and SJT15 -112m; sample 34: alkali feldspar granite dike.

\begin{tabular}{|c|c|c|c|c|c|c|c|c|c|c|c|}
\hline Sample & 1 & 4 & 25 & 26 & 27 & 30 & 32 & 33 & 34 & SJT101 & SJT112 \\
\hline$\overline{\mathrm{Si} 02}$ & 68.8 & 67 & $\begin{array}{l}66.04 \\
\end{array}$ & 71 & 68.41 & 72 & 71.9 & 67.9 & $\begin{array}{l}65.3 \\
\end{array}$ & 67.7 & 65.96 \\
\hline $\mathrm{Ti} 02$ & 0.6 & 0.6 & 0.58 & 0.5 & 0.6 & 0.53 & 0.5 & 0.6 & 0.61 & 0.61 & 0.65 \\
\hline Al203 & 14.6 & 14.8 & 15.02 & 13.7 & 15.1 & 14.4 & 14.3 & 14.2 & 15.8 & 15.7 & 16.03 \\
\hline $\mathrm{Cr} 203$ & 0.01 & 0.07 & 0.002 & 0.01 & 0.01 & 0 & 0.03 & 0.02 & 0 & 0 & 0.003 \\
\hline $\mathrm{Fe} 203$ & 1.42 & 2.25 & 2.66 & 2.02 & 1.22 & 1.69 & 2.05 & 2 & 2.56 & 3.4 & 3.79 \\
\hline $\mathrm{MnO}$ & 0.01 & 0 & 0.01 & 0.1 & 0 & 0.02 & 0 & 0.01 & 0.01 & 0.01 & 0.01 \\
\hline $\mathrm{MgO}$ & 0.7 & 1.1 & 0.91 & 1.6 & 0.8 & 0.94 & 1.3 & 1 & 1.4 & 1.54 & 2.37 \\
\hline $\mathrm{CaO}$ & 0.3 & 0.2 & 0.15 & 0.3 & 0.3 & 0.85 & 2.8 & 0.2 & 0.29 & 0.4 & 1.35 \\
\hline $\mathrm{Na} 20$ & 0.58 & 0.56 & 0.47 & 0.33 & 0.25 & 3.07 & 3.84 & 0.46 & 0.77 & 3.34 & 4.39 \\
\hline K20 & 11.1 & 10.8 & 11.53 & 8.51 & 11 & 4.51 & 1.65 & 10.7 & 10.5 & 4.15 & 2.5 \\
\hline P205 & 0.2 & 0.2 & 0.01 & 0.2 & 0.2 & 0.16 & 0.2 & 0.2 & 0.18 & 0.21 & 0.19 \\
\hline Lol & 1.3 & 1.8 & 1.7 & 1.2 & 1.5 & 1.6 & 1.1 & 1.6 & 1.8 & 2.6 & 2.5 \\
\hline Total & 99.62 & 99.38 & 99.22 & 99.5 & 99.39 & 99.8 & 99.67 & 98.89 & 99.2 & 99.6 & 99.74 \\
\hline$(\mathrm{Nb} / \mathrm{Zr}) \mathrm{N}$ & 1.14 & 1.02 & 1.01 & 1.01 & 1.04 & 1.08 & 1.03 & 0.89 & 0.97 & 0.97 & 0.86 \\
\hline $\mathrm{Ba}$ & 1987 & 1840 & 1626 & 1261 & 1273 & 189 & 126 & 2016 & 1280 & 306 & 431 \\
\hline $\mathrm{Rb}$ & 258 & 251 & 276.9 & 202 & 272 & 165 & 56.5 & 246 & 297 & 154 & 119 \\
\hline $\mathrm{Sr}$ & 124 & 125 & 71 & 72 & 97 & 218 & 360 & 108 & 102 & 77.1 & 174 \\
\hline $\bar{Y}$ & 7 & 13.3 & 11.7 & 15.1 & 17.8 & 9.7 & 14.6 & 5.8 & 12.2 & 7.3 & 7.2 \\
\hline $\mathrm{Zr}$ & 157 & 176 & 175.9 & 167 & 177 & 157 & 149 & 183 & 170 & 184 & 183.7 \\
\hline $\mathrm{Nb}$ & 11.4 & 11.4 & 11.3 & 10.7 & 11.7 & 10.8 & 9.8 & 10.4 & 10.3 & 11.2 & 10 \\
\hline Th & 10.2 & 11.9 & 7.9 & 8.3 & 9.1 & 5.3 & 6.1 & 10.4 & 7.4 & 6.6 & 4.2 \\
\hline$\overline{\mathrm{Pb}}$ & 9.7 & 7.8 & 8.2 & 8.4 & 9.2 & 12.1 & 9.2 & 6.1 & 6.9 & 51.2 & 7.7 \\
\hline Ga & 14 & 18 & 13 & 18 & 14 & 18.6 & 19 & 15 & 17.3 & 23 & 24.5 \\
\hline $\mathrm{Zn}$ & 29 & 22 & 23 & 11 & 6 & 141 & 255 & 20 & 31 & 81 & 63 \\
\hline $\mathrm{Cu}$ & 1557 & 3371 & 4336 & 2883 & 4324 & 715 & 1945 & 6971 & 4044 & 2050 & 733.9 \\
\hline $\mathrm{V}$ & 48 & 66 & 63 & 52 & 57 & 53 & 61 & 52 & 65 & 59 & 72 \\
\hline $\mathrm{Hf}$ & 4.2 & 5.1 & 4.7 & 4.3 & 5 & 4.1 & 4 & 5.9 & 5 & 5.2 & 5 \\
\hline Cs & 3.4 & 3.6 & 4.3 & 3.5 & 4.6 & 5.5 & 3 & 3.2 & 6.2 & 9.3 & 9 \\
\hline Sc & 4 & 5 & 5 & 6 & 5 & 5 & 6 & 5 & 6 & 5 & 7 \\
\hline$\overline{\mathrm{T}} \mathrm{a}$ & 1.1 & 1 & 0.9 & 0.9 & 1 & 1.1 & 1 & 1 & 1.1 & 0.9 & 1.3 \\
\hline$\overline{C_{0}}$ & 3.4 & 4.4 & 4.2 & 1.9 & 1 & 3.7 & 7.5 & 3.5 & 5 & 13.3 & 7.9 \\
\hline $\mathrm{Be}$ & 2 & 1 & 4 & 1 & 1 & 1 & 1 & 1 & 1 & 2 & 4 \\
\hline U & 5.2 & 4 & 2.9 & 2.3 & 3.5 & 1.4 & 1.5 & 4.2 & 3.7 & 3.9 & 2.4 \\
\hline W & 38 & 42 & 32.1 & 30 & 51 & 25.4 & 47 & 39 & 56.2 & 32.7 & 3.6 \\
\hline Sn & 12 & 15 & 19 & 23 & 18 & 5 & 8 & 30 & 17 & 9 & 2 \\
\hline$\overline{M_{0}}$ & 4.6 & 13 & 9.7 & 1.6 & 2.4 & 2.5 & 6.2 & 4.6 & 1.5 & 4.4 & 6.3 \\
\hline$\overline{\mathrm{Au}}$ & 431 & 57.1 & 11.8 & 58.4 & 89.4 & 21.5 & 270 & 171 & 64.2 & 236 & 44.1 \\
\hline $\mathrm{Ni}$ & 47 & 230 & 9.8 & 32 & 37 & 10.4 & 116 & 92 & 7.7 & 9.5 & 12.4 \\
\hline As & 43.9 & 36 & 273.2 & 12.4 & 148 & 123 & 78.1 & 62.3 & 75.6 & 384 & 40.2 \\
\hline $\mathrm{Cd}$ & 0.1 & 0.1 & 0.1 & 0.1 & 0.1 & 1 & 5.3 & 0.1 & 0.3 & 0.7 & 0.2 \\
\hline $\mathrm{Sb}$ & 0.6 & 0.8 & 3.5 & 0.4 & 2 & 2.1 & 1.6 & 0.4 & 0.9 & 1 & 0.3 \\
\hline$\overline{B i}$ & 7.2 & 7 & 10.3 & 25 & 22 & 1.9 & 19 & 15 & 8.3 & 11.6 & 1.6 \\
\hline $\mathrm{Ag}$ & 0.3 & 0.5 & 0.6 & 1 & 1.1 & 0.5 & 1.1 & 1.1 & 0.8 & 0.8 & 0.4 \\
\hline $\mathrm{Tl}$ & 0.1 & 0.1 & 0.1 & 0.1 & 0.1 & 0.1 & 0.1 & 0.1 & 0.1 & 0.1 & 0.4 \\
\hline $\mathrm{Se}$ & 0.9 & 0.8 & 7.2 & 0.5 & 1.4 & 0.5 & 1.2 & 2.8 & 0.9 & 4.8 & 0.9 \\
\hline La & 3.1 & 52.3 & 27.7 & 32.2 & 36.4 & 5.5 & 10 & 6.7 & 21.1 & 21 & 3.8 \\
\hline $\mathrm{Ce}$ & 8.3 & 108 & 55.7 & 67 & 73.4 & 14.7 & 29.9 & 14.4 & 44.8 & 42.1 & 8.6 \\
\hline$\overline{\mathrm{Pr}}$ & 1.05 & 11.84 & 6.42 & 7.19 & 8.1 & 1.92 & 4.04 & 1.74 & 4.94 & 4.54 & 1.15 \\
\hline $\mathrm{Nd}$ & 5.3 & 42 & 24.9 & 27 & 28 & 9.8 & 18 & 7.4 & 19.3 & 17.4 & 5.1 \\
\hline $\mathrm{Sm}$ & 1.5 & 7.5 & 4.6 & 5.4 & 5.5 & 2.17 & 4.2 & 1.5 & 3.73 & 2.99 & 1.27 \\
\hline$\overline{E u}$ & 0.4 & 0.67 & 0.59 & 0.74 & 1.08 & 0.59 & 0.94 & 0.38 & 0.73 & 0.45 & 0.61 \\
\hline$\overline{\mathrm{Gd}}$ & 1.8 & 4.99 & 4.07 & 4.35 & 4.72 & 2.12 & 3.56 & 1.54 & 3.18 & 2.48 & 1.49 \\
\hline$\overline{\mathrm{Tb}}$ & 0.3 & 0.6 & 0.57 & 0.7 & 0.7 & 0.32 & 0.5 & 0.2 & 0.49 & 0.31 & 0.23 \\
\hline Dy & 1.7 & 3.2 & 2.63 & 3.4 & 3.6 & 1.52 & 2.7 & 1.2 & 2.62 & 1.43 & 1.28 \\
\hline $\mathrm{H}_{0}$ & 0.3 & 0.5 & 0.47 & 0.6 & 0.7 & 0.36 & 0.5 & 0.2 & 0.44 & 0.3 & 0.21 \\
\hline$\overline{E r}$ & 0.75 & 1.18 & 1.27 & 1.55 & 1.79 & 0.86 & 1.44 & 0.5 & 1.2 & 0.82 & 0.71 \\
\hline $\mathrm{Tm}$ & 0.1 & 0.2 & 0.2 & 0.2 & 0.3 & 0.12 & 0.2 & 0.1 & 0.18 & 0.12 & 0.11 \\
\hline$\overline{Y b}$ & 0.7 & 1.3 & 1.22 & 1.5 & 1.9 & 0.73 & 1.4 & 0.6 & 1.08 & 0.66 & 0.63 \\
\hline Lu & 0.1 & 0.2 & 0.18 & 0.2 & 0.2 & 0.13 & 0.2 & 0.1 & 0.16 & 0.13 & 0.14 \\
\hline
\end{tabular}




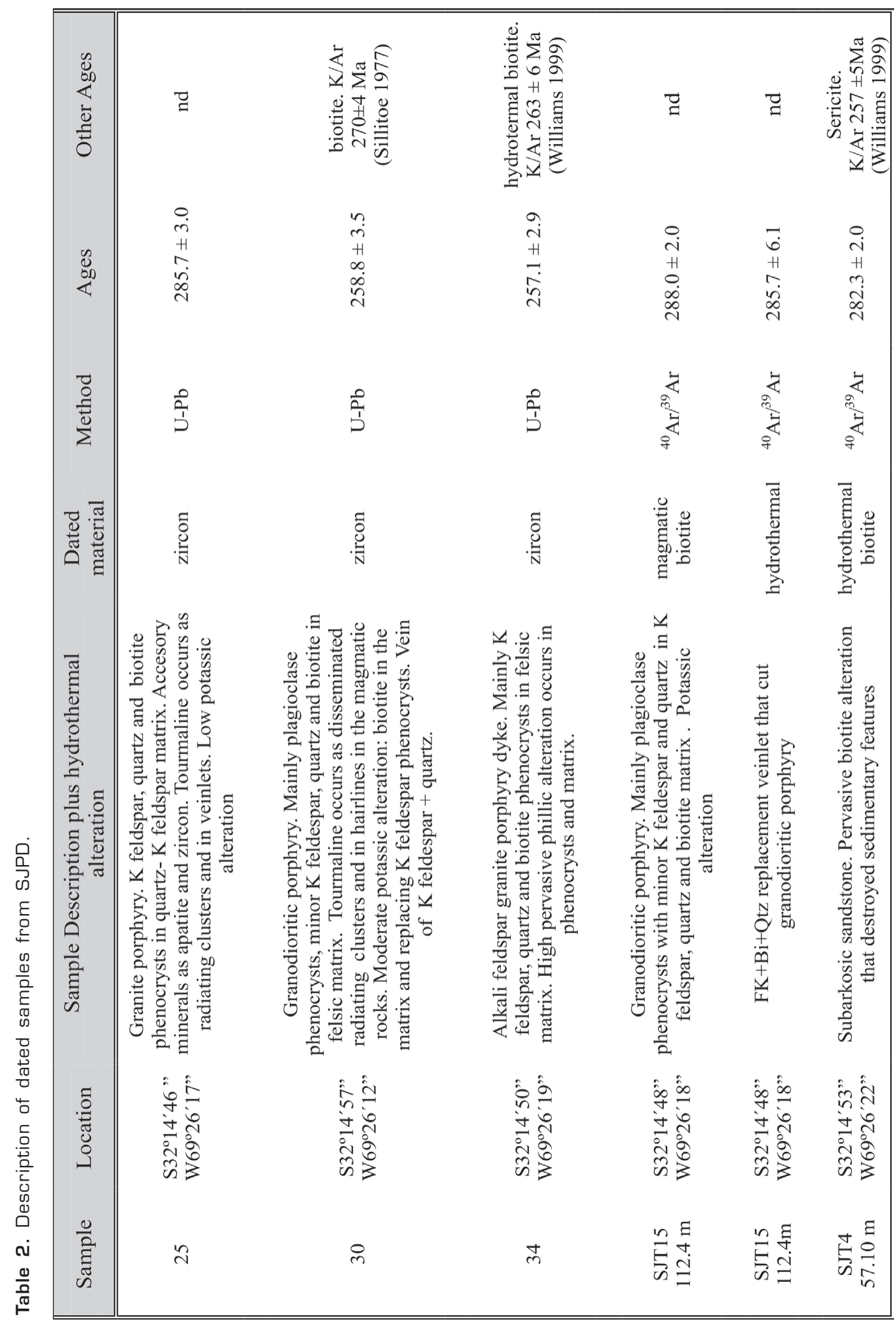


M. M. Garrido et al.: Petrography, geochemistry and geochronology of San Jorge porphyry...

$\left.{ }_{39} \mathrm{Ar}\right) \mathrm{Ca}=0.3952 \pm 0.0004, \mathrm{Ca} / \mathrm{K}=1.83 \pm 0.01$ $(37 \mathrm{ArCa} / 39 \mathrm{ArK}))$. Details of the analyses, including plateau 7 (spectrum) and inverse correlation plots, are presented in Excel spreadsheets. Initial data entry and calculations were carried out using the software ArArCalc (Koppers 2002). The plateau and correlation ages were calculated using Isoplot ver.3.09 (Ludwig 2003). Errors are quoted at the 2 -sigma ( $95 \%$ confidence) level and are propagated from all sources except for mass spectrometer sensitivity and age of the flux monitor.

For the U/Pb dating three samples (25, 30 and 34) were dated using the U-Pb single zircon laser ablation multicollector ICP-MS technique, sample 25 from a granite porphyry, sample 30 from a granodiorite porphyry and sample 34 from an alkali-feldspar granitic dike. The samples were crushed and milled, and zircons were handpicked under a binocular microscope. They were mounted in epoxy and polished for laser ablation analysis. Textural studies were conducted using a microscope or scanning electron microscope; prior to analysis the zircons were selected by size and crystallographic integrity. That is, the crystal should not have cracks or altered outer surfaces, and the system behaviour should have remained isotopically closed and their $\mathrm{U}$, Th and $\mathrm{Pb}$ dates be concordant (Richards and Noble 1998). Zircons were analysed by LA-MC-ICP-MS (Laser Ablation Multi Collector Inductively Coupled Plasma Mass Spectrometry) at the Centro de Excelencia en Geotermia de los Andes (CEGA), at the University of Chile. The ablation system used is an ArF excimer laser with a wavelength of $193 \mathrm{~nm}$ (Photon Machine Analyte G2) coupled to the Neptune Plus MC-ICP-MS instrument (Thermo Scientific). The laser was operated at a frequency of $7 \mathrm{~Hz}$ and its ablation diameter was $30 \mu \mathrm{m}$. The calibration of the MC-ICPMS was performed by ablation of standard Plesovice zircons (Slama et al., 2008). The data reduction is performed by the operator with the Iolite software (Paton et al., 2010) and the results are plotted with the Excel Isoplot supplement (Ludwig, 2012).

\section{RESULTS}

PETROGRAPHY

In the deposit the porphyry rocks, based on phenocrystal composition and proportions, were identified as granite and two granodiorites (G1 and G2) and an alkali feldspar dike. The granite porphyry analysed in this work is equivalent to the granodiorite porphyry described by Williams et al. (1999). All these rocks intrude subarkosic grey sandstone, with quartz clasts up to 172 $\mu \mathrm{m}$ in size, from the Yalguaráz sequence (SJT4- $57.10 \mathrm{~m}$, Fig. 2 and 4b) that according to Williams et al. (1999) host the main mineralization.

The granite porphyry is light grey with porphyritic texture and outcrops in the central part of the deposit (Fig.2). The phenocrystal to groundmass relations are 40:60, and K-feldspar, quartz, plagioclase and biotite are phenocrystals (Fig. 3A). Euhedralsubhedral cloudy K-feldspar and quartz are the most abundant and range from 2 to 8 $\mathrm{mm}$ in size (Fig. 3B). Plagioclase crystals are scarce and are altered to sericite. Primary biotite crystals range from 0.5 to $3.5 \mathrm{~mm}$. The groundmass is composed of fine-grained quartz, feldspar and biotite with zircon and apatite as accessory minerals.

Two granodiorite porphyries were determined. The first granodiorite porphyry (G1) is located at drill core SJT15 where a lithological change from granite porphyry at the surface to granodiorite porphyry at a depth of 101-112.4 $\mathrm{m}$ has been observed (Fig. 3C and Fig. 4a). The contact between both rocks seems to be transitional. It has phenocryst to groundmass relations of $60 \%-40 \%$ and is dominated by plagioclase with quartz, $\mathrm{K}$ feldspar and biotite. Plagioclase phenocrysts (oligoclase-andesine) are coarse ranging in size from 3 to $13 \mathrm{~mm}$. Quartz crystals are anhedral, 1.2 to $4 \mathrm{~mm}$ in size. K-Feldspar (orthoclase) phenocrysts are scarce like biotite. The groundmass feldspars and quartz are generally $<0.1 \mathrm{~mm}$ in size (Fig. 3C). The second granodiorite porphyry (G2) is located at the eastern margin of the Gorda fault (Fig. 2 , samples 30 and 32 ). It clearly crosscuts 
the granite porphyry and has a phenocryst to groundmass ratio of 60:40. Phenocrysts are mostly plagioclase and quartz with sizes up to $2.5 \mathrm{~mm}$. Biotite and K-feldspar pheno- crysts are smaller and less abundant (Fig. $3 \mathrm{E})$. The groundmass is felsic, and zircon and apatite are present as accessory minerals.
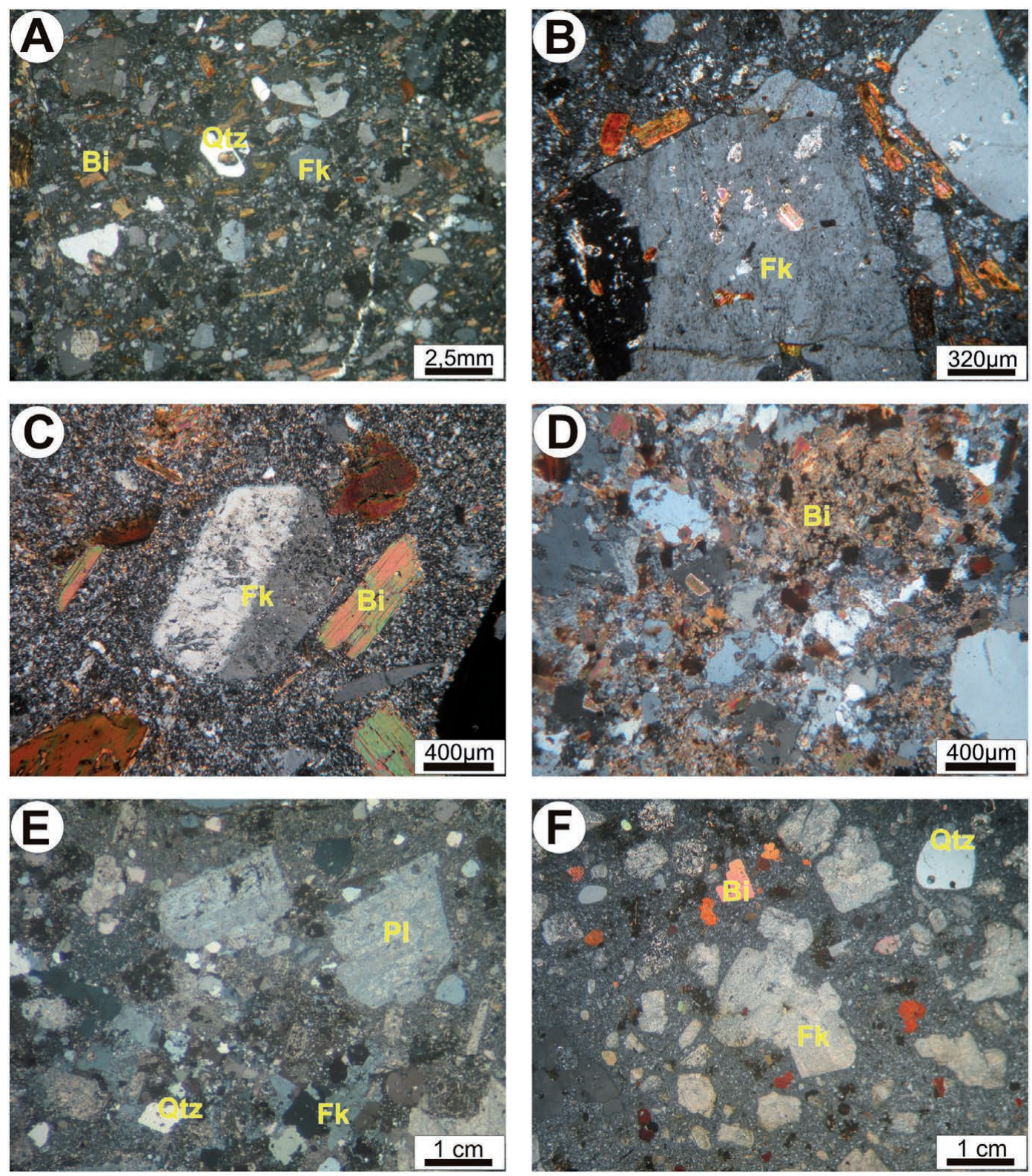

Figure 3. A) Granite porphyry with quartz, feldspar and biotite phenocrystals in felsitic groundmass. B] Detailed view of $\mathrm{K}$ feldspar phenocrystal with cloudy appearance. C) Granodiorite porphyry G1. Mainly plagioclase phenocrysts with minor K-feldspar and quartz in felsitic groundmass (drillhole, SJT15-112.4 m). D) K feldspar, biotite and quartz replacement veinlet that crosscuts granodiorite porphyry G1 (in drillhole SJT15-112.4 m). E) Granodiorite porphyry G2 (sample 30) showing plagioclase, quartz and biotite phenocryst in a felsitic groundmass. F) Alkali-feldspar granite porphyry dike (sample 34). Qtz:quartz; Kfs: K-feldspar; Pl: plagioclase; Bt: biotite. 


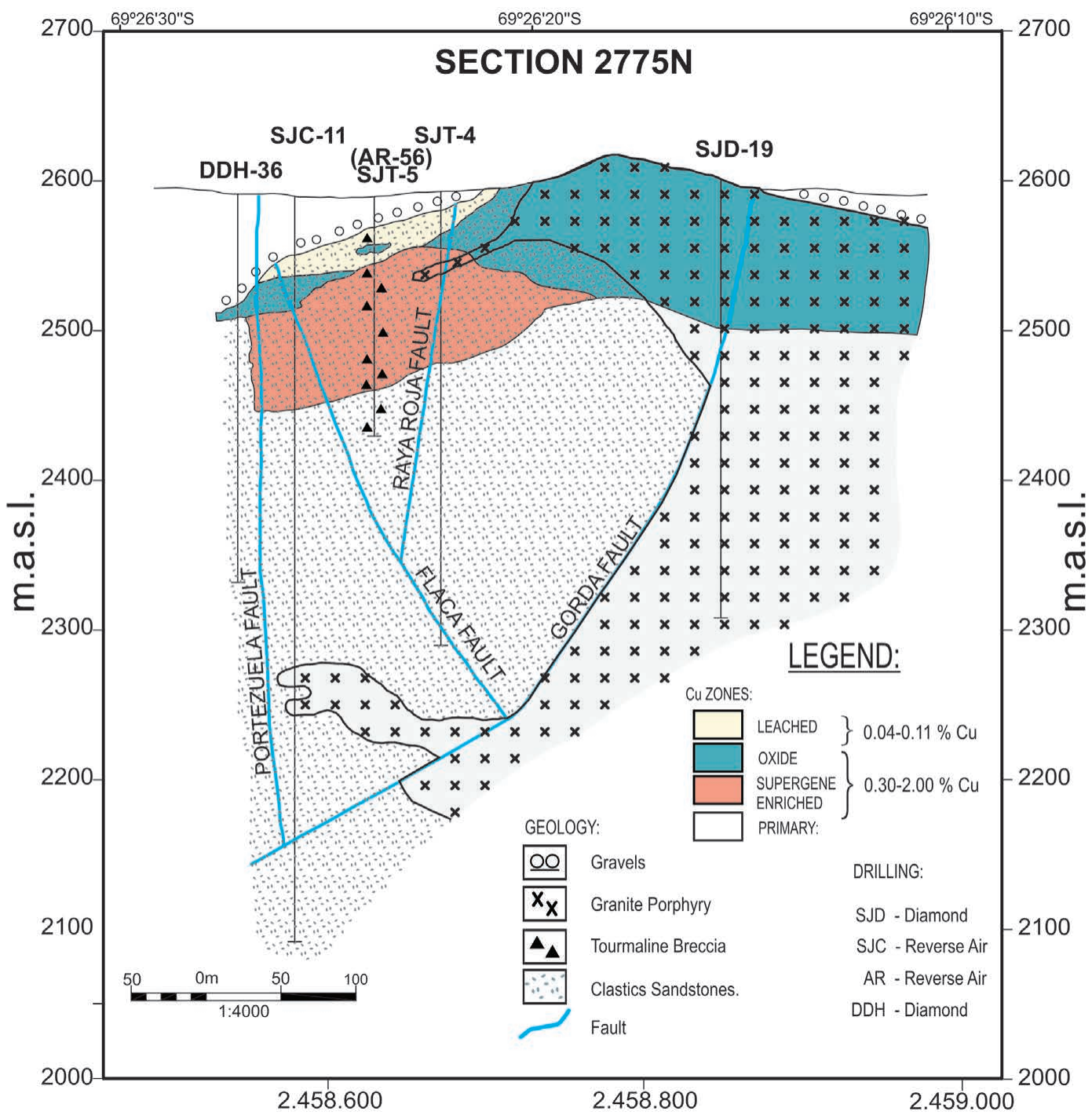

Figure 4a. Section 2775N. Taken and modified by Compañía Minera San Jorge SA (2008).

An alkali-feldspar granite porphyry dike crosscuts the granite porphyry in the centralSW area and is equivalent to the andesitic dike described by Williams et al. (1999). The dike (sample 34) has a porphyritic texture with abundant and coarse K-feldspar phenocrysts $(<8 \mathrm{~mm})$ and minor plagioclase, biotite and quartz. The groundmass has a felsic composition (Fig. 3F).

\section{GEOCHEMISTRY}

Major, trace and rare earth element chemical analyses of granite, granodiorite porphyries and the alkali-feldspar dike are shown in Table 1.

The spider diagram of trace elements and the REE diagram have been normalized to primordial mantle (Taylor and McLennan 1985) and chondrite (Boynton 1984) respectively (Fig. 5a and 5b). The granite, granodiorite porphyries and alkali feldspar dike show an enrichment in $\mathrm{Rb}, \mathrm{U}$, Hf and $\mathrm{Zr}$, and 


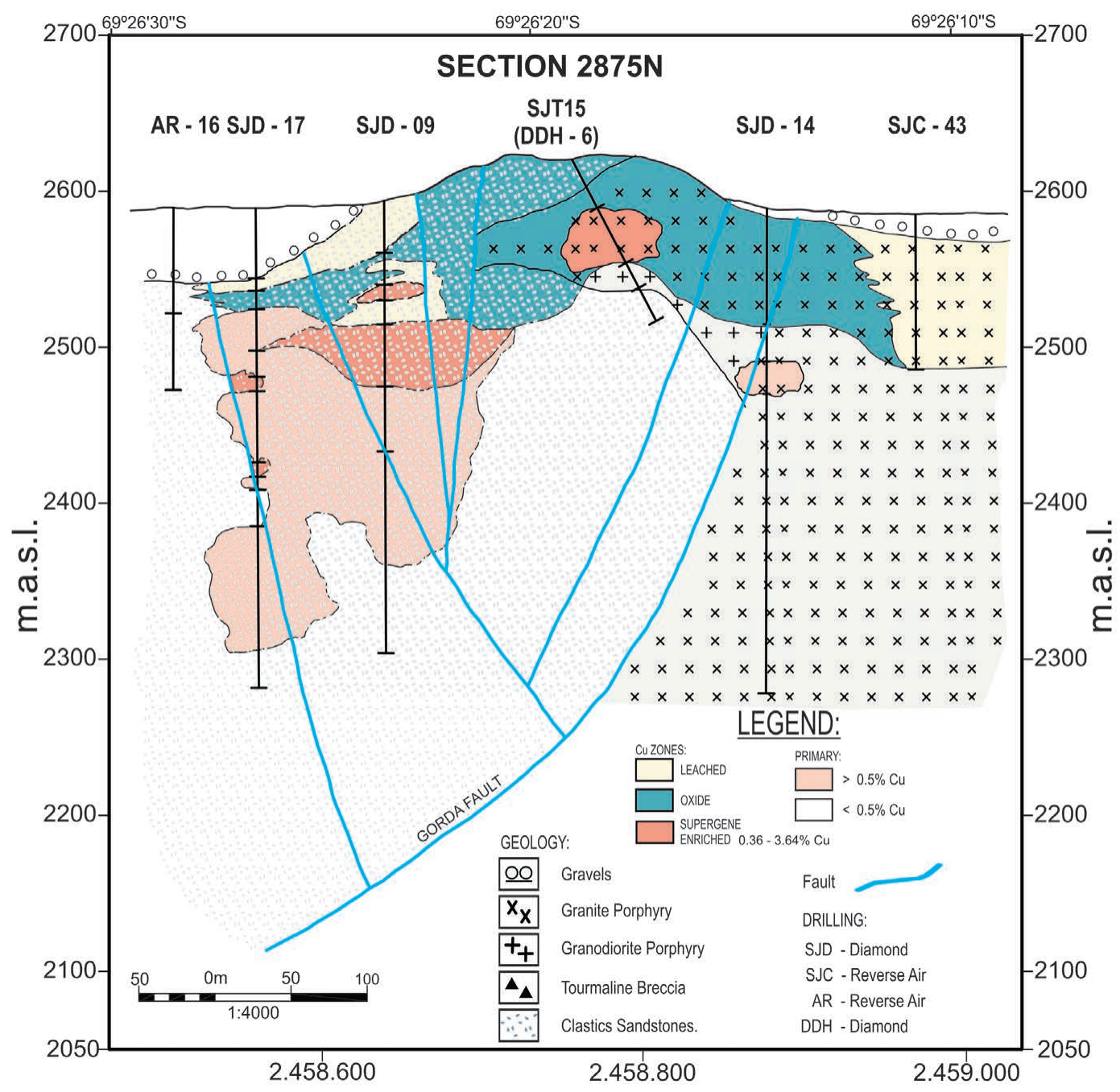

Figure 4b. Section 2875N. Taken and modified by Compañía Minera San Jorge SA (2008).

a depletion in Th, Nb, Ta and Y. The spider diagram of these types of rocks (Fig.5a) indicates that LILEs are enriched relative to HFSEs with the Rb concentration being the highest related to others trace elements. $\mathrm{Ba}$ is enriched in granites and alkali feldspar dike and depleted in the granodiorites. Sr is higher in granodiorites than granites and dike. $\mathrm{Nb}$ and Ta negative anomaly is indicative of a continental margin zone magmatism according to Pearce (1984). A minor negative anomaly in La and Ce in granodiorites in G1 and G2 is observed. La and Ce anomaly is not observed in the REE diagram.
The total rare earth element content (LREEs) is 25 to $166 \mathrm{ppm}$ for granites and 25 to 95 ppm for granodiorites. The granite is enriched in light rare earth elements (LRREs) related to granodiorite, with (La/ $\mathrm{Yb})_{\mathrm{N}}$ ratios of 12.9 to 15.4 and 4.1 to 5.1 respectively. The granite shows a significant negative Eu anomaly suggesting plagioclase fractionation compatible with Sr negative anomaly. The granodiorites (G1 and G 2) show a slightly negative Eu anomaly. They present a constant level of HREEs and do not show any trend consistent with the fractionation of any particular phase represented by 
garnet or hornblende (Fig. 5b). The Ta vs $\mathrm{Nb}$ tectonic diagram enables the discrimination between arc, within-plate, collisional and orogenic granites (Pearce et al. 1984). The studied samples plot between volcanic arc and syn-collisional granites (Fig. 5c). In the $\mathrm{Zr}$ vs $(\mathrm{Nb} / \mathrm{Zr})$ diagram, the samples plot mainly in the field of subduction-zone magmatism and post-orogenic zone rocks reported by Thiéblemont and Tegyey (1994) (Fig. 5d).

A

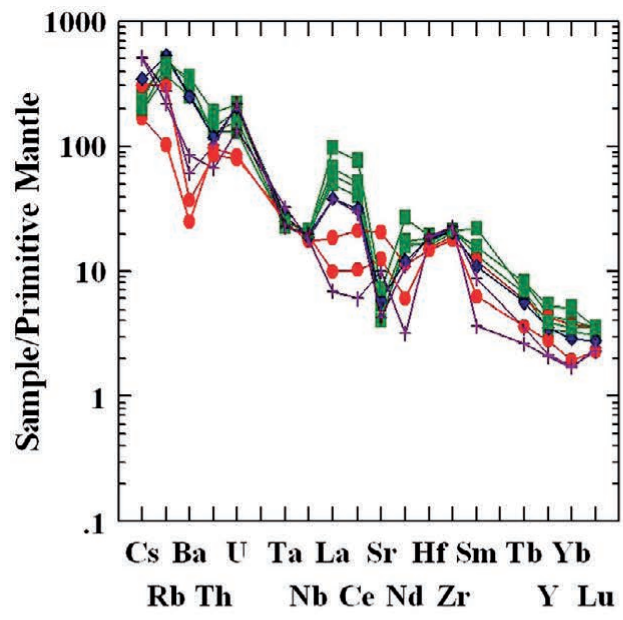

C

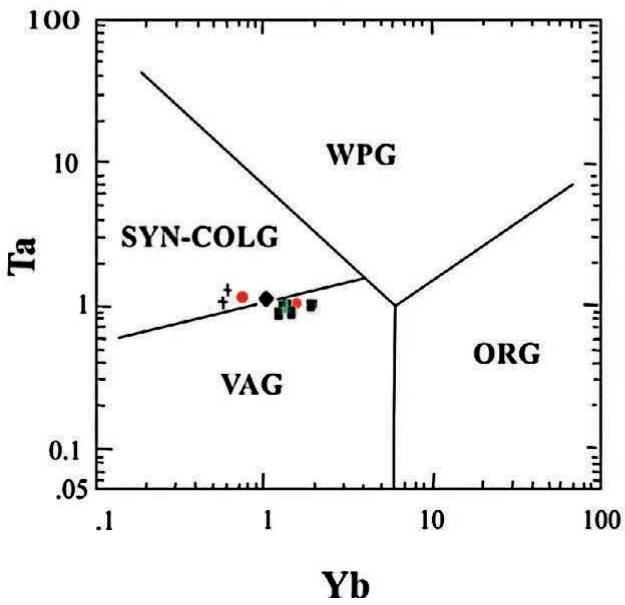

\section{ALTERATION AND MINERALIZATION}

Detailed hydrothermal alteration studies were done over surface samples, and on SJT15, SJT4; in SJT5 drill hole some results were taken from Garrido et al. (2010). The earlier type of alteration has been identified as tourmalinization. Tourmaline occurs as radial fibrous crystals replacing feldspar and quartz phenocrystals of granite porphyry (Fig. 6A and B); there is a second tourma-

B

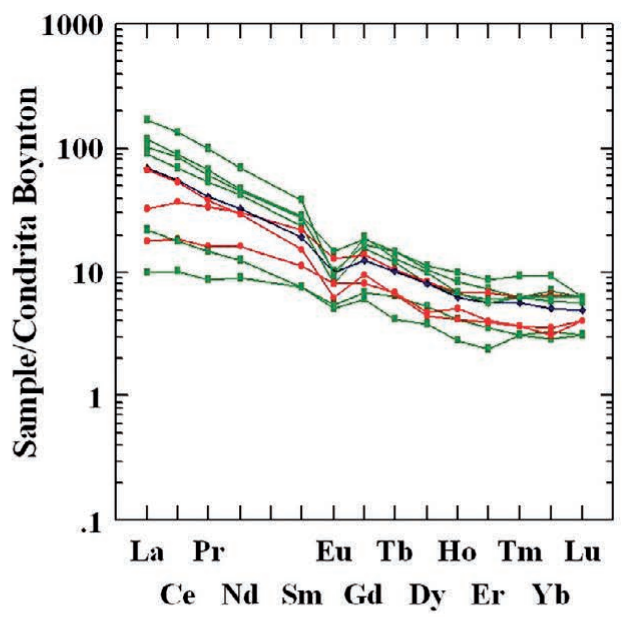

D

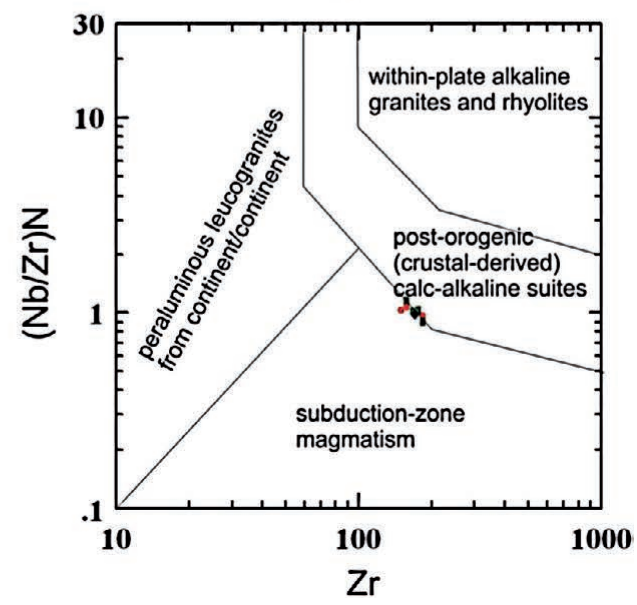

Figure 5. A) Normalized to primordial mantle (Sun and McDonough 1989) diagram of SJPD. B) Chondrite normalized REE diagram (Boynton 1984). C) Ta vs Yb diagram (Pearce et al. 1984). D) $\mathrm{Zr}$ vs $(\mathrm{Nb} / \mathrm{Zr})_{\mathrm{N}}$ diagram of Thieblemont and Tegyey (1994). 
line event as breccias cement in the granite porphyry and sedimentary rocks (Fig. 6C). Following the tourmalinization, potassic and phyllic events occurred affecting the granite porphyry, the sandstone wall rock (Yalguaráz Formation) and the tourmaline breccia body (Garrido et al. 2010).
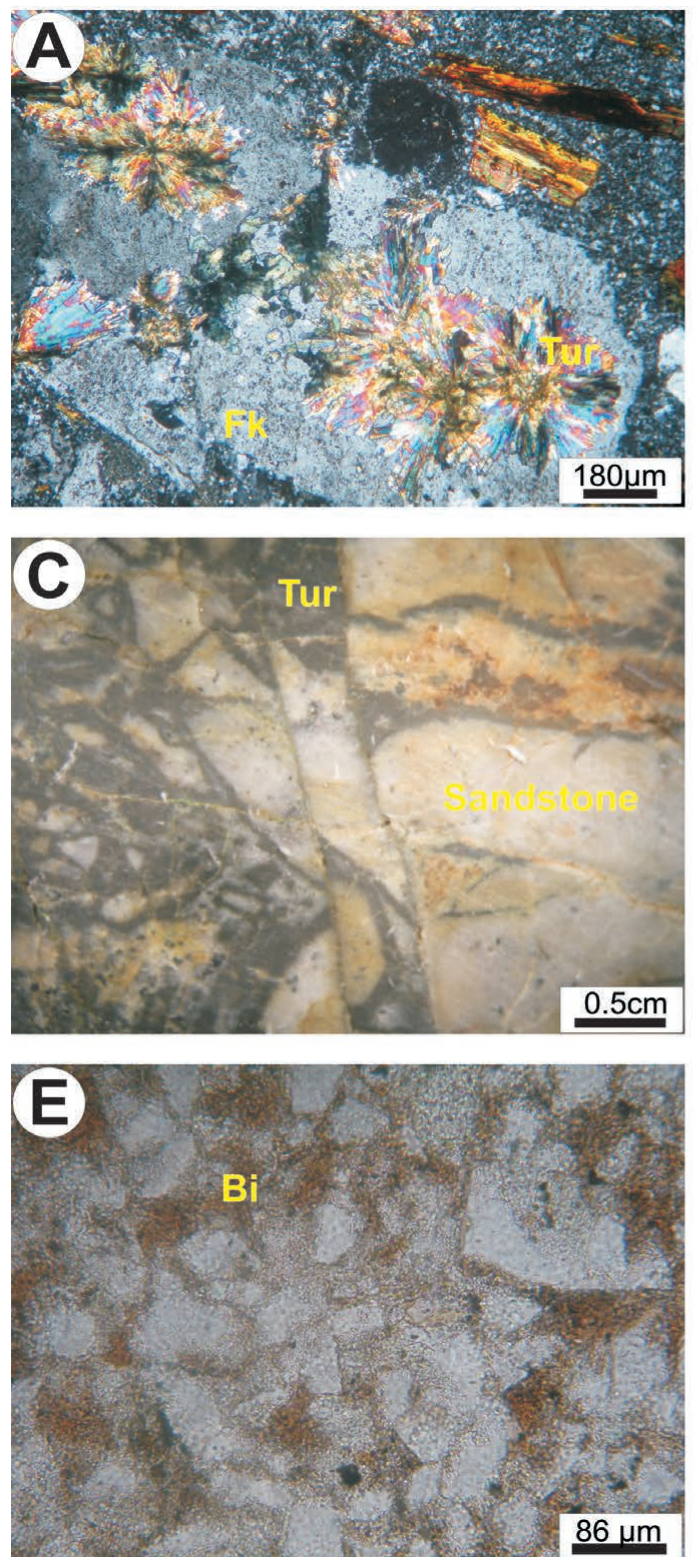

Potassic alteration is represented by biotite, K-feldspar, quartz, associated with pyrite and chalcopyrite. Biotite occurs as pervasively in sandstones (SJT4-57.10m, Fig.6D and $6 \mathrm{E})$, G1 granodiorite porphyry groundmass (Fig. 3C), and in veinlets (SJT15-112m, Fig. 3D). These veinlets also have K-feldspar,
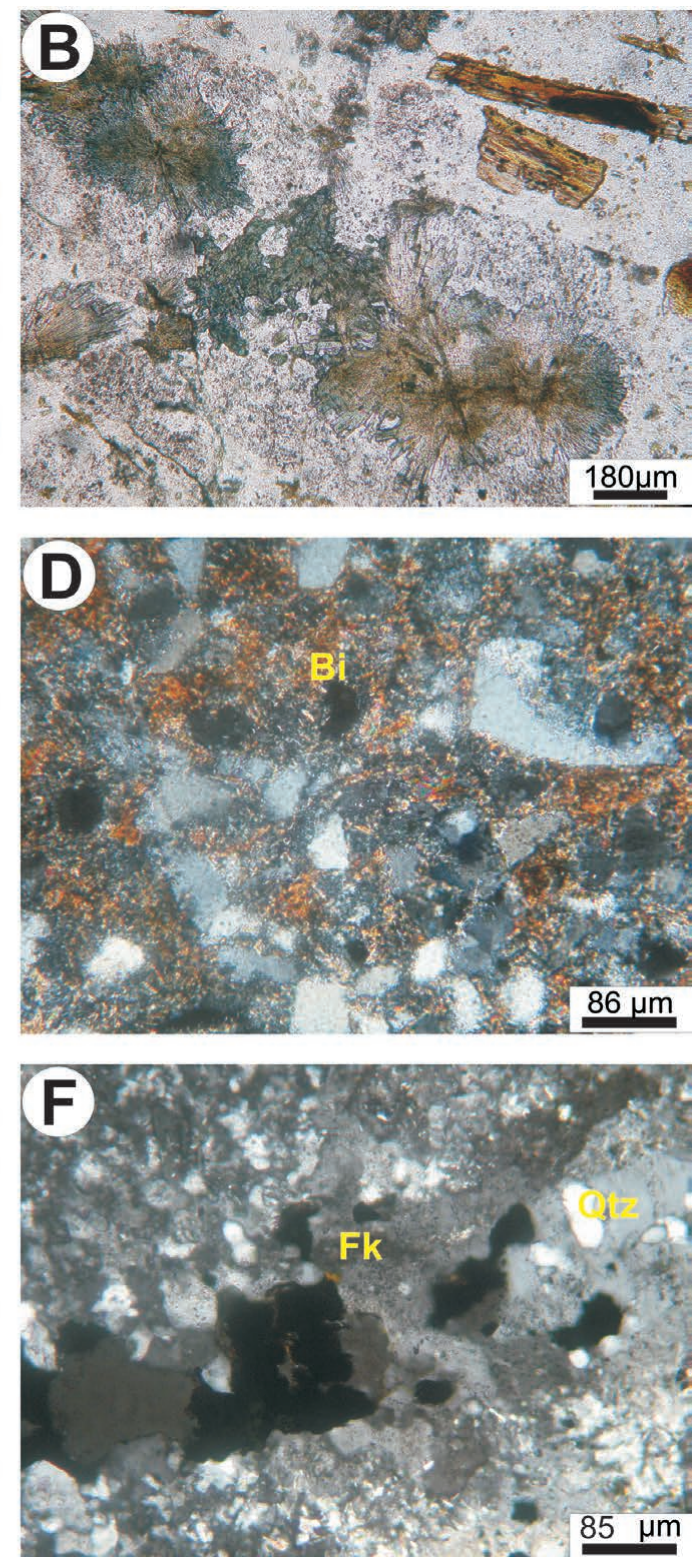

Figure 6. A] Tourmaline soles as replacement of potassic feldspar in granite porphyry. B] Same as A with plane polarized light. C) Handspecimen of tourmaline breccia. D) Sandstone with potassic alteration. Disseminated biotite in the groundmass (drillhole SJT4- 57.10m). Cross polarized light. E) Same as $D$ with plane polarized light. F) Potassic alteration veinlet with quartz, K-feldspar and sulphides. 

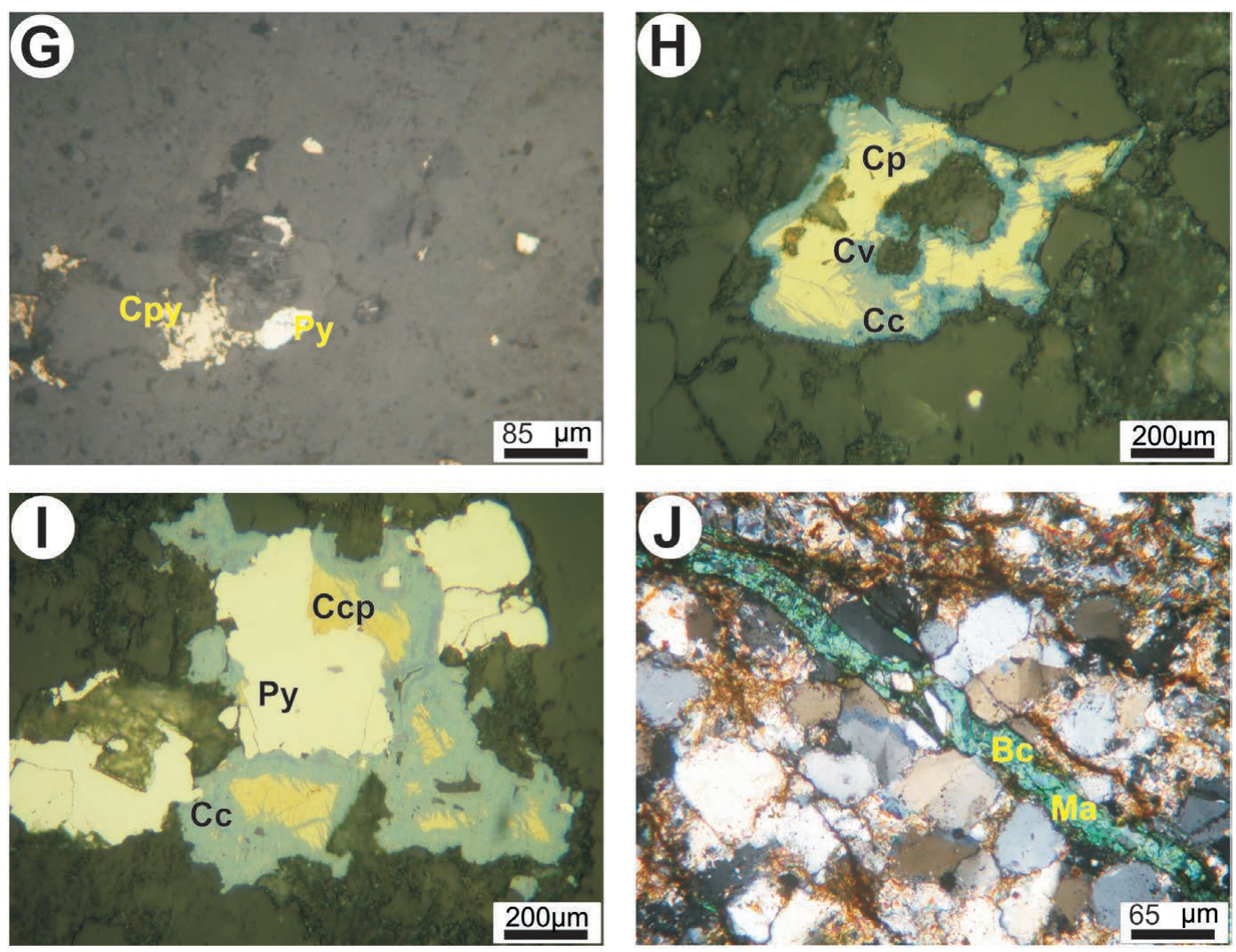

Figure 6, continuation. G) Same as F showing pyrite (py) and chalcopyrite (cpy). H)- Chalcocite (Cc) and covellite (Cv) halos as replacement of chalcopyrite (Ccp). I) Pyrite and chalcopyrite surrounded by chalcocite. J) Brochantite (Bro) and malachite (Ma) vein that crosscut tht sandstone rock.

quartz, chalcopyrite and pyrite (Fig. 6F and G); quartz and biotite; quartz with minor K-feldspar or biotite that crosscut the granodiorite porphyry (Fig. 3D) .

The potassic alteration is overprinted by a phyllic alteration that consists of veinlets of quartz and sericite; sericite; and quartz, pyrite, chalcopyrite and arsenopyrite. Williams et al. (1999) found that the phyllic alteration zone has an elongated shape with a dominant NNE-SSW direction with potassic mineralized cores. The mineralization occurs in the granite porphyry and in the sedimentary sequence that has the highest $\mathrm{Cu}$ contents $(1 \%$ to $3 \%)$. At the Western margin of the Gorda fault, the total sulphide content is $1 \%$ with Py:Cpy $<<1$. The phyllic alteration has an external pyrite halo with pyrrhotite, arsenopyrite and minor chalcopyrite, dis- seminated in the granite porphyry and disseminated and in veinlets in the sandstone.

Supergene minerals consist of digenite, chalcocite and covellite in the enriched zone (Fig.6H and I); malachite and brochantite (Fig. 6J) in the oxide zone; and goethite, hematite and jarosite in the gossan zone.

\section{GEOCHRONOLOGY}

With $40 \mathrm{Ar} / 39 \mathrm{Ar}$ three incremental heating age spectra were obtained: one spectra is on magmatic biotite and two spectra are on hydrothermal biotites. One hydrothermal biotite is related to a replacement veinlet and the other to a pervasive alteration in sandstone (Table 2). The best estimate of the age from the igneous biotite phenocrysts in the granodiorite porphyry G1 (drill core, SJT15- 
$112.4 \mathrm{~m}$ ) gives a plateau age of $288.0+/-2.0$ Ma (Fig.7A). The reverse isochron forced through the air composition of argon is within error, confirming the age (Fig. 7A').
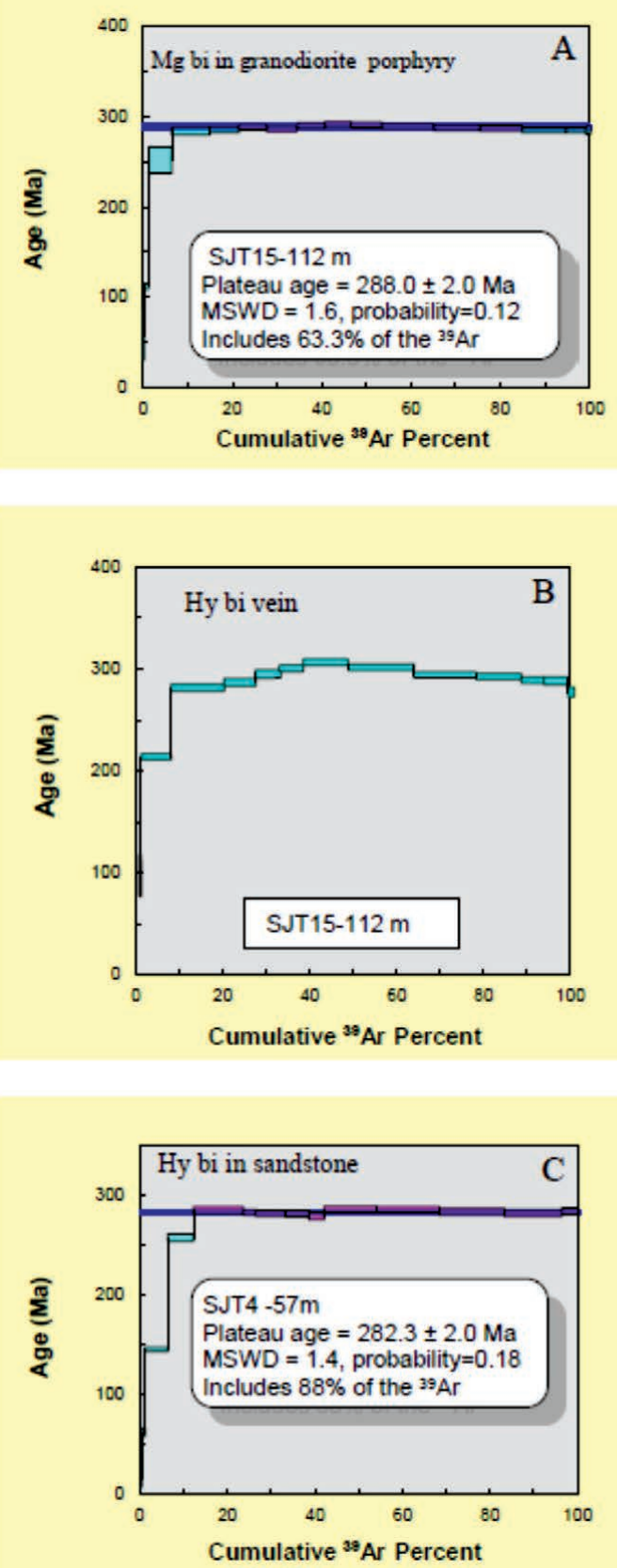

The age determination of hydrothermal biotite from replacement veinlet (drill core SJT15-112.4m) shows the step heating profile without a clear plateau (Fig. 7B). The
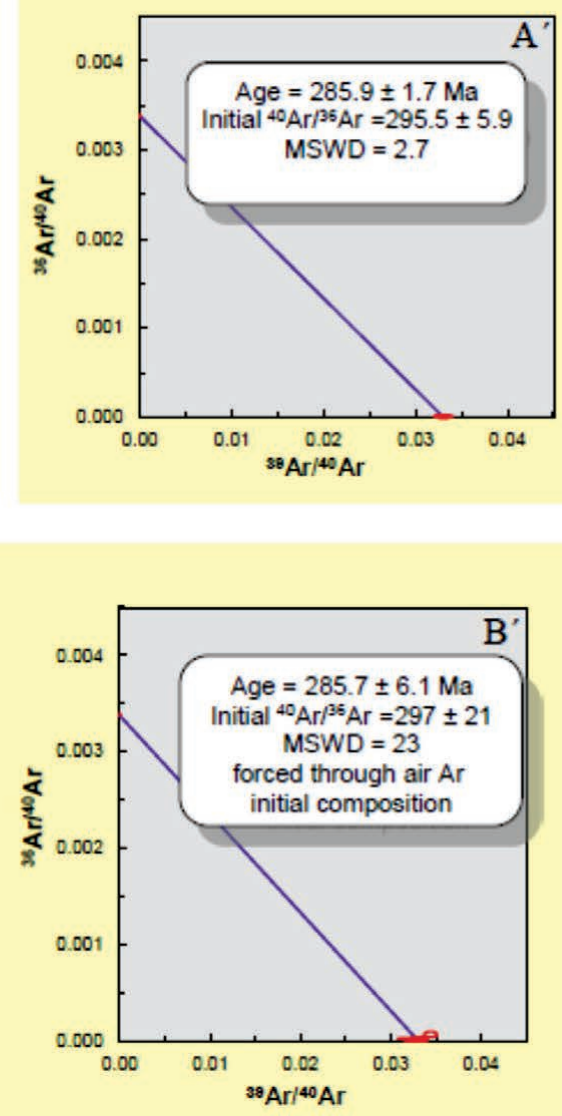

Figure 7. ${ }^{40} \mathrm{Ar} /{ }^{39} \mathrm{Ar}$ age spectrum for biotites in drilling samples and their inverse isochron diagrams respectively of: A ) and A') magmatic biotite (mag bi) from granodiorite G1, SJT15-112.4m; B) and B'] hydrothermal biotite (hy bi) vein from SJT15-112.4m; C) and C'] hydrothermal biotite from sandstone, SJT4-57.10m. 
argon systematics is definitely disturbed, probably due to the hydrothermal vein. The reverse isochron age is $285.7+/-6.1 \mathrm{Ma}$ (Fig.7B').

The best estimate of the age from hydrothermal pervasive biotite (drill core
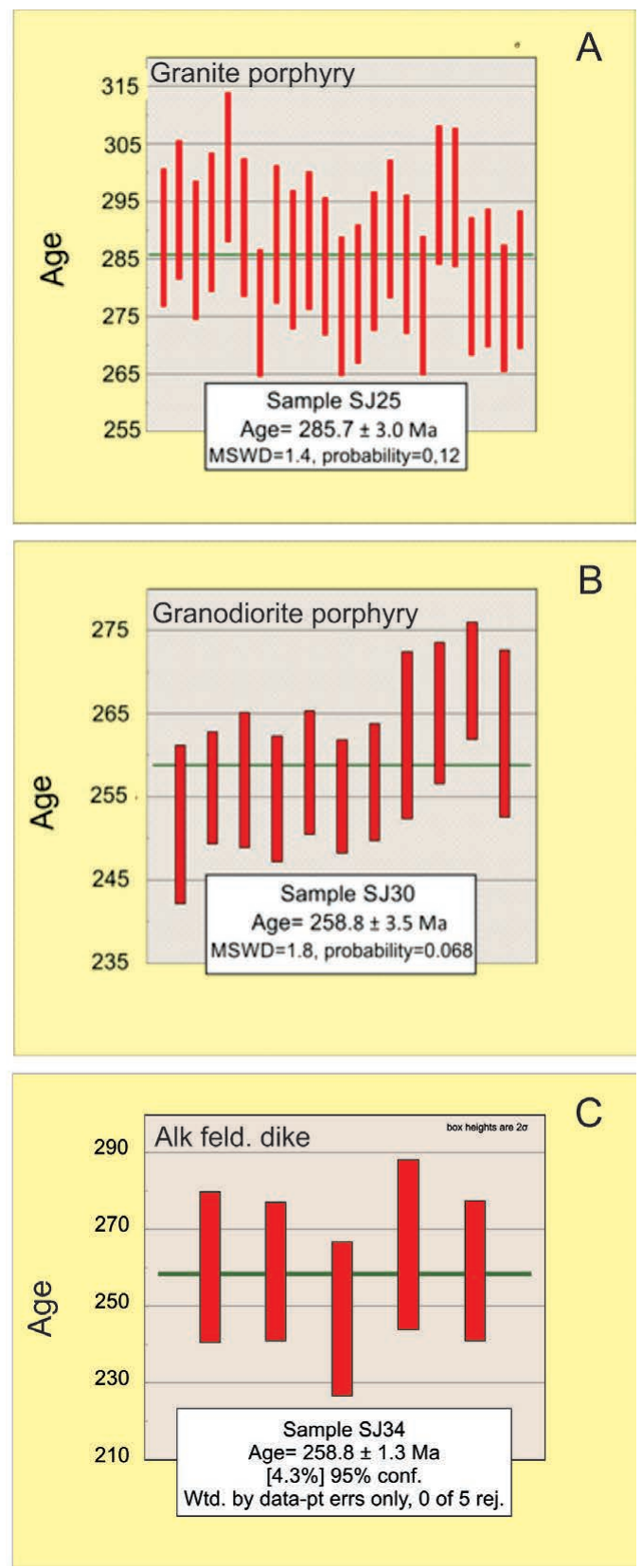

Figure 8. $U / \mathrm{Pb}$ weighted average plot for $\mathbf{A}]$ granite porphyry, B) granodiorite porphyry G2, and $\mathbf{C}$ ) alkali-feldspar granite dike.
SJT4-57.10m) is given by the plateau age of $282.3+/-2.0 \mathrm{Ma}$. The reverse isochron forced through the air composition of argon is within error, confirming the age (Table 3, Fig. 7C and C').

For the U/Pb dating twenty-seven zircon grains were measured from the granite porphyry (sample 25, Fig. 2). The doubly-terminated prismatic zircons analysed are light greenish to colourless and range from 70 to $125 \mu \mathrm{m}$ in size. Zircons from this sample have $U$ concentrations that vary from 423 to $1374 \mathrm{ppm}$. Cathodoluminescence images show that the zircons present the well-developed growth zoning characteristic of evolved magmas (Corfu et al. 2003).The results are shown in Fig. 8a, b, and c; each bar represents a spot analysis. These zircons yielded a weighted average $206 \mathrm{~Pb} / 238 \mathrm{U}$ age of $285.7 \pm$ $3 \mathrm{Ma}(\mathrm{n}=27, \mathrm{MSWD}=1.4$; Table 4, Fig. 8a). No inherited zircon was recognized.

For the granodiorite porphyry G2, sixteen zircon grains were analysed (sample 30 ). Zircons from this sample have U concentrations that vary from 595 to 1357 ppm and yielded a weighted average $206 \mathrm{~Pb} / 238 \mathrm{U}$ age of $258.8 \pm 3.5$ Ma (MSWD=1.8; Table 5, Fig. 8b). Five grains yielded a Permian inherited component ( $\sim 273$ and $284 \mathrm{Ma})$.

For the alkali feldspar granite porphyry dike (sample SJ34) only sixteen from twenty-seven zircon analysed grains were chosen; eleven analysed grains were disregarded because they represent inherited zircons (in bold) and $\mathrm{Pb}$ loss (in italics). The sixteen analysis selected yielded $206 \mathrm{~Pb} / 238 \mathrm{U}$ ages with a weighted mean of $257.1 \pm 2.9$ $\mathrm{Ma}, \mathrm{MSWD}=1.4$, probability 0.14 . (Table 6; Fig.8c). However, age variation range is higher than $50 \mathrm{Ma}$ ( 289Ma and $231 \mathrm{Ma}$ ). Therefore, the best results are obtained considering only five samples yielding $206 \mathrm{~Pb} / 238 \mathrm{U}$ ages with a weighted mean of $258.4 \pm 1.3$ Ma. (Fig. 8c).

\section{DISCUSSIONS}

The rocks found in San Jorge deposit were a granite porphyry, two granodiorite porphyries; one in SJT15 at 112 m (G1), 


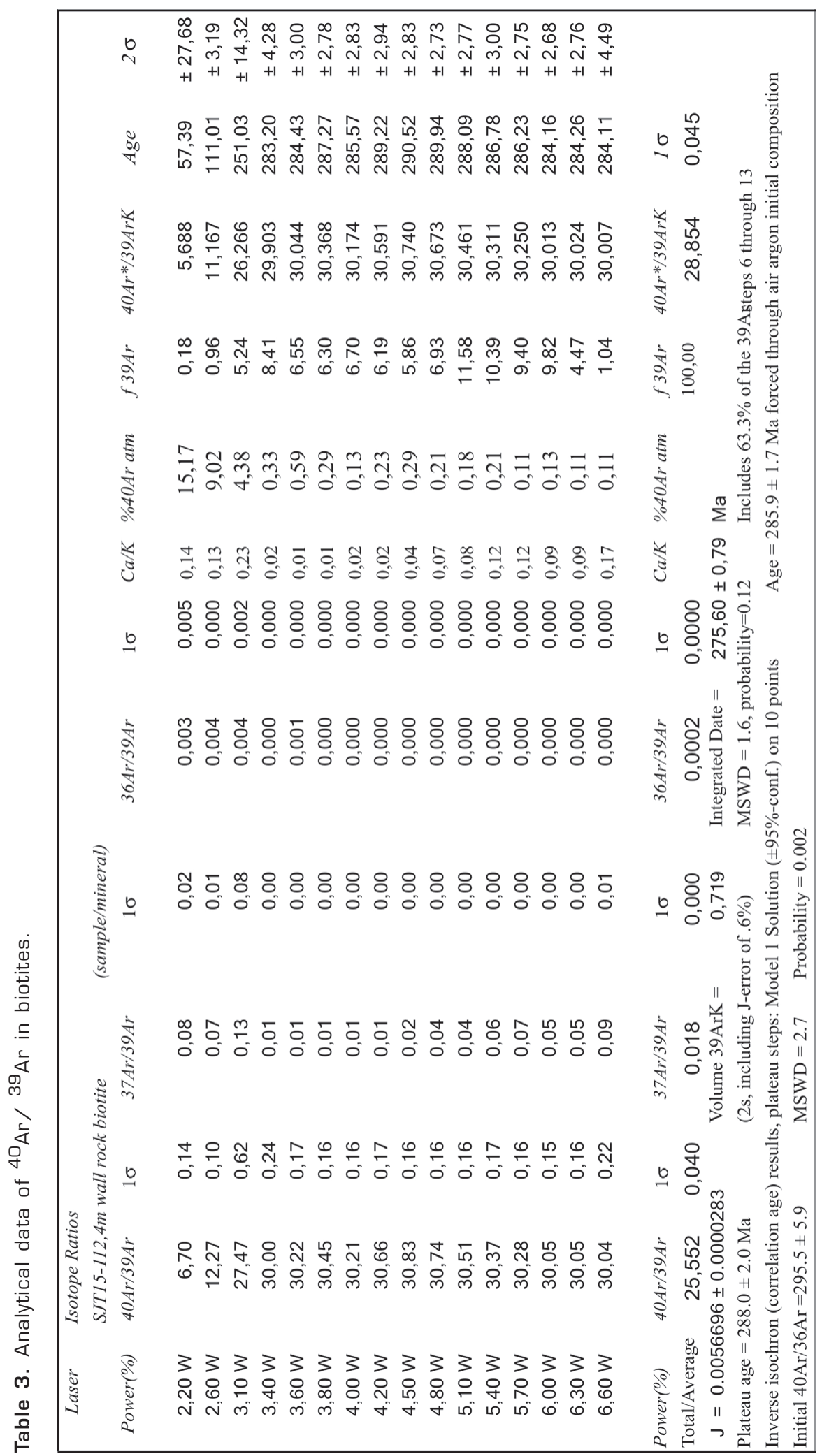




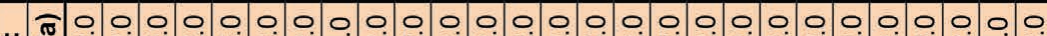

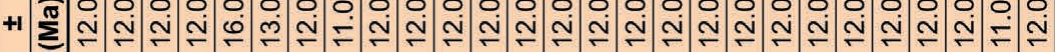
D.

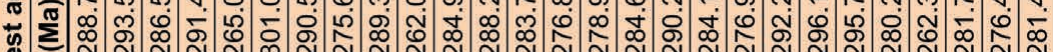
๓े

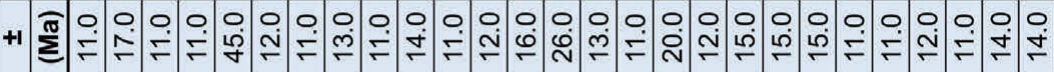

g

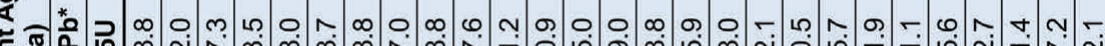

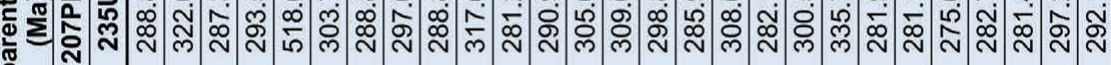
$\frac{0}{2}$

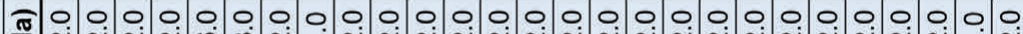

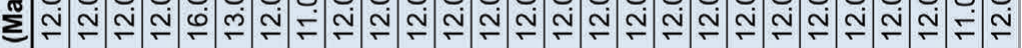

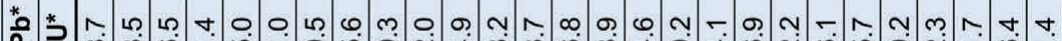
○

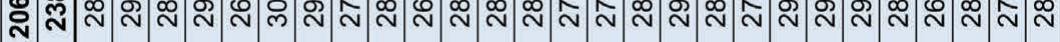

๓ 융융ㅇㅇㅇㅇㅇㅇㅇㅇㅇㅇㅇㅇㅇㅇㅇㅇㅇㅇㅇㅇㅇㅇ

+1 ○

*

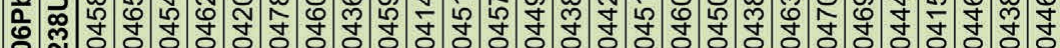

N

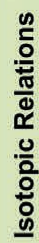

๓ ส

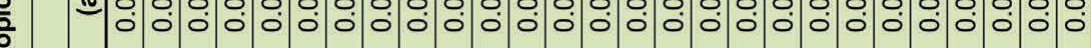

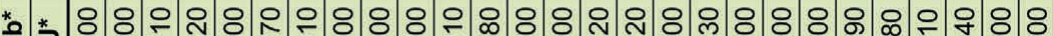

金点

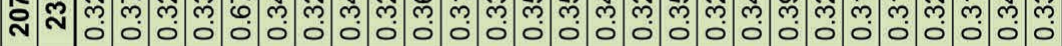

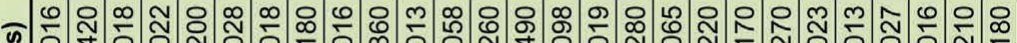

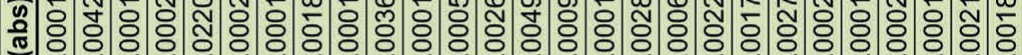

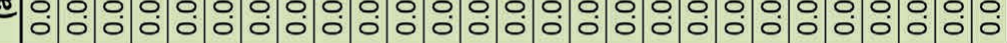

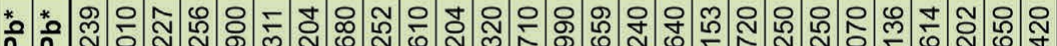

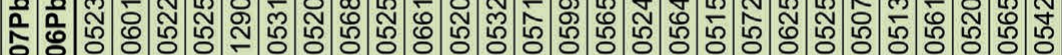
సิ

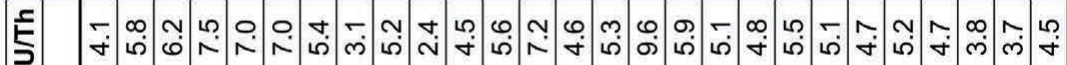

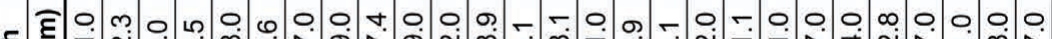

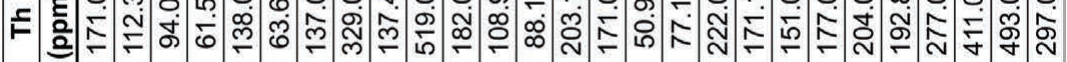

E L 응 గூூ̆

$\stackrel{\circ}{\frac{1}{2}}$ 
other (G2) on the eastern margin of the Gorda fault, and an alkali-feldspar granite dike. The alkali-feldspar granite dike crosscuts the granitic porphyry and is contemporaneous with the granodiorite porphyry G2 (Fig. 2).

The geochemical characteristics from spider diagram show $\mathrm{Nb}$ and Ta negative anomaly indicative of a continental margin zone magmatism according to Pearce (1984). The $\mathrm{Ta}$ vs Nb tectonic diagram enables the discrimination between arc, within-plate, collisional and orogenic granites. The studied samples plot mainly between volcanic arc and syn-collisional granites.

Based on the new biotites $40 \mathrm{Ar} / 39 \mathrm{Ar}$ ages and zircon $\mathrm{U}-\mathrm{Pb}$ ages in granites show that there are two periods of time for hydrothermal magmatic system. The first group is early Permian and was obtained on the granitic porphyry (sample 25), on magmatic biotite in the granodiorite porphyry G1 (SJT15 at $112.4 \mathrm{~m}$ ), and on two biotites from the potassic alteration (SJT15 at $112.4 \mathrm{~m}$; SJT4 at $57.10 \mathrm{~m})$.

The two ages from the granodiorite G1 and the granite 25 suggest that the magmatism related to the formation of porphyry copper appears to be within period of time, between $290 \mathrm{Ma}$ and $283 \mathrm{Ma}$, (early Perm- ian, Fig. 9). The evidences show transitional contact between these rocks and similar geochemical patterns suggest they are probably genetically linked. The $40 \mathrm{Ar} / 39 \mathrm{Ar}$ ages on hydrothermal biotites (in vein and pervasive) indicate the associated mineralization overlaps with the granite age $(25, \mathrm{U} / \mathrm{Pb})$ and continuous by 2 million years after intrusive emplacement.

In the second group is late Permian, appears to be within period of time between $263 \mathrm{Ma}$ and $254 \mathrm{Ma}$, (Fig.9) and are represented by the granodiorite porphyry G2 (sample 30) and the alkali feldspar granite dike (sample 34). G2 outcrops in the southern part of the deposit and it is separated from granite porphyry by an inferred fault (Gorda fault). Evidences of mineralization are not observed in this group.

The copper mineralization and alterations occur in the sandstones from the Yalguaráz Formation and in lesser amount in the granite porphyry. A hydrothermal biotite from a vein that crosscuts the granodiorite porphyry G1 (SJT15-112.4 m, $288 \mathrm{Ma} 40 \mathrm{Ar}$ / $39 \mathrm{Ar})$ yielded $285.7 \pm 6.1 \mathrm{Ma}(40 \mathrm{Ar} / 39 \mathrm{Ar})$ age, and a pervasive hydrothermal biotite in sandstone (SJT4-57.10 m) gave an age of $282.3 \pm 2.0 \mathrm{Ma}(40 \mathrm{Ar} / 39 \mathrm{Ar})$. These two

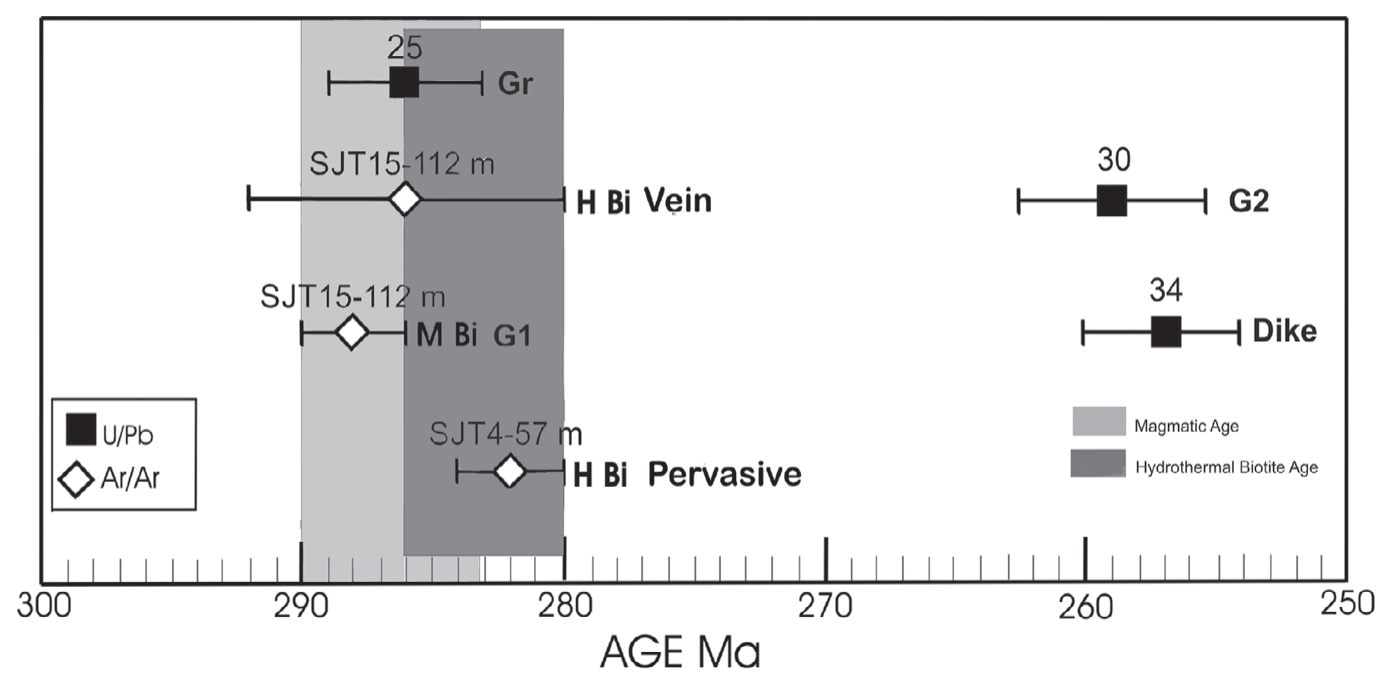

Figure 9. Summary of the timing of igneous and hydrothermal episodes at San Jorge porphyry copper deposit. 25- Granite porphyry; 30- Granodiorite porphyry G2; 34- Alkali feldspar granite dike; SJT15, SJT4 drillholes; MBi: magmatic biotite; HBi: hydrothermal biotite. 
ages overlap with the granite porphyry age $(285.7 \pm 3 \mathrm{U} / \mathrm{Pb})$ suggesting that the potassic alteration is related to the early Permian granite porphyry (Fig. 9) and the hydrothermal system remains active during 2 Ma post emplacement of granite.

Mpodozis and Ramos (1990) defined an Early Permian (286-272 Ma) metallogenic province in the less eroded parts of a volcanoplutonic arc developed along the Gondwana Pacific margin in Chile and western Argentina. In this province there are several porphyry copper deposits, being San Jorge deposit one of them. On the other hand, porphyry copper occurrences in Chile and western Argentina yielded Late Permian to Early Jurassic ages and are part of a large granite-rhyolite igneous province named Choiyoi (Kay et al 1989). LLambias and Sato (2011) and Sato et al (2015), define Choiyoi Magmatic Province between an Early Permian San Rafael orogenic phase and the Triassic extensional Huarpica phase in the region of Argentine Frontal Cordillera, Precordillera and San Rafael Block (U/Pb 286-247 Ma, Early Permian-Early Triassic).

In this paper, according to new $\mathrm{U} / \mathrm{Pb}$ and ${ }^{40} \mathrm{Ar} / 39 \mathrm{Ar}$ geocronological results, mineralized and no mineralized San Jorge granites integrate the intrusive event of the Choiyoi Group. The obtained ages differ from K-Ar age of $270 \pm 4 \mathrm{Ma}$ (Sillitoe 1977) on magmatic biotite from a granodiorite stock (denominated as granite porphyry in this paper) and from K-Ar age of 263 \pm 6 Ma (Williams et al. 1999) on hydrothermal biotite from porphyritic andesite dike (denominated alkali feldspar granite porphyry in this paper).

\section{CONCLUSIONS}

The detailed petrography indicates that in the deposit the igneous activity has undergone two episodes. The first is represented by granite and granodiorite porphyry G1 and the second by another granodiorite porphyry G2 and a dike. The granite porphyry and the alkali-feldspar granite dike correspond to the granodiorite porphyry and andesite dike described by Williams et al. (1999).
Spider diagram show $\mathrm{Nb}$ and Ta negative anomaly indicative of a continental margin zone magmatism according to Pearce (1984). The $\mathrm{Ta}$ vs $\mathrm{Nb}$ tectonic diagram enables the discrimination between arc, within-plate, collisional and orogenic granites (Pearce et al. 1984). The studied samples plot mainly between volcanic arc and syn-collisional granites.

An Early Permian magmatic event is responsible for the granite and granodiorite porphyry G1 intrusions and the potassic alteration-mineralization. A second event of Late Permian age is represented by the granodiorite porphyry G2 and the alkali feldspar granite dike. The results indicate the hydrothermal system in Early Permian, continued for $2 \mathrm{Ma}$ after the emplacement of the intrusive body.

The results suggest that the evolution of the western margin of Gondwana began in late Carboniferous and continued during the Permian period. In this Paleozoic to early Jurassic metallogenic belt, La Voluntad Cu-Mo porphyry is the oldest deposit (early Pennsylvanian, Garrido et al. 2008). Mineralized and no mineralized San Jorge granites (Early Permian-Late Permian) integrate the intrusive event of the Choiyoi Group.

\section{ACKNOWLEDGMENTS}

We are grateful to the Universidad Nacional del Sur (Bahia Blanca, Argentina) for the financial support through research grants (SECYT) and PICT 2013-2713 of ANPCYT. We also thank Dr Angelo Peri (Vice President of Exploration of the Mining Company Coro Mining Corporation) for allowing us access to the deposit and especially to Geologist Alejandro Palma (Compañía Minera San Jorge, Argentina) for his logistical support and for facilitating the access to samples of the drilling holes needed to carry out this study. We wish to thank Dr. Fernando Barra for performing $\mathrm{U} / \mathrm{Pb}$ analysis. We also appreciate the support given by Dr Eduardo A. Domínguez for very helpful discussions on the manuscript. 


\section{REFERENCES}

Amos AJ and Marchese HG (1965) Acerca de una nueva interpretación de la estructura del Carbónico en la Ciénaga del Medio. Revista de la Asociación Geológica Argentina 20 (2): 263-270.

Amos AJ and Rolleri EO (1965) El Carbónico marino en el Valle de Calingasta-Uspallata (San Juan y Mendoza). Boletín de Informaciones Petroleras 368: 1-23. Buenos Aires.

Boynton WV (1984) Geochemistry of the rare earth elements: meteorite studies. In: Henderson P editor. Rare earth element geochemistry. Elsevier 63-114.

Camus F (1998) Porphyry cooper systems in the Andes. In: Re Kuhl, G editor. Cordillera de los Andes: The New tectonic and Metallogenic Approach. GRK Servicios Mineros, Mendoza 71-73.

Camus F (2003) Geología de los sistemas porfíricos en los Andes de Chile. Servicio Nacional de Geologia y Mineria, Chile, $267 \mathrm{p}$.

Compañía Minera San Jorge S.A (2008) San Jorge copper concentrator project 266p. PDF file www.coromining.com.

Corfu F, Hanchar JM, Hoskin PWO, Kinny P (2003) Atlas of Zircon textures. Rev Miner \& Geochem, 53: 468-500.

Garrido M, Barra F, Domínguez E, Ruiz J, Valencia VA (2008) Late Carboniferous porphyry copper mineralization at La Voluntad, Neuquén, Argentina: Constraints from Re-Os molybdenite dating. Mineralium Deposita 43 (5): 591-597.

Garrido M, Gómez C, Fernandez ML y Lambrecht S (2010). Brecha de turmalina del yacimiento de pórfido de cobre-oro San Jorge, Mendoza. Alteración, mineralización y origen de los fluidos. Revista de la Asociación Geológica Argentina 67 [1]: 47-57.

Kay SM, Ramos VA, Mpodozis C, Sruoga P, (1989). Late Paleozoic to Jurassic silicic magmatism at the Gondwana land margin; analogy to Middle to Proterozoic in North America. Geology 17: 324-328.

Koppers AAP (2002) ArArCALC - software for $40 \mathrm{Ar} / 39 \mathrm{Ar}$ age calculations. Computers and Geosciences 28: 605-619.

Llambías EJ (1999). Las rocas ígneas gondwánicas. Instituto de Geología y Recursos Minerales Geología Argentina. Anales 29 12: 349-376. Buenos Aires.

LLambias and Sato (2011). Ciclo Gondwanico: La Provincia Magmática Choiyoi en Neuquén. Relatorio delL XVIII Congreso Geológico Argentino. 53-62.
Ludwig KR (2003) Isoplot 3.09. A Geochronological Toolkit for Microsoft Excel. Berkeley Geochronology Center, Special Publication No 4.

Ludwig K R (2012). Isoplot 3.75. A Geochronological Toolkit for Microsoft Excel. Berkeley Geochronology Center, Special Publication No 5.

Mpodozis C and Ramos VA (1989) The Andes of Chile and Argentina. In Ericksen GE, Cañas Pinchoet, MT, Reinemundy JA editors. Geology of the Andes and its relation to hydrocarbon and mineral resources. Circum Pacific Council for Energy and Mineral Resources Earth Sciences Series 11: 59-90 Houston.

Mpodozis C and Ramos VA (1990) The Andes of Chile and Argentina. In: Ericksen GE, Cañas Pinochet MT and Reinemud JA editors. Geology of the Andes and its relation to Hydrocarbon and Mineral Resources, Circumpacific Council for Energy and Mineral Resources, Earth Sciences Series 11:59-90 Houston.

Mpodozis C and Kay S (1992) Late Paleozoic to Triassic evolution of the Gondwana margin: evidence from Chilean Frontal Cordillera batholiths (28ㅇ S to 31으. Geological Society of America Bulletin 104: 999-1014.

Pearce JA, Harris NBW and Tindel AJ (1984) Trace element discrimination diagram for the tectonic interpretation of granitic rocks. Journal of Petrology 25: 956- 983.

Renne PR, Swisher C, Deino CC, Karner AL, Owens DBT and DePaolo DJ (1998) Intercalibration of standards, absolute ages and uncertainties in 40Ar/39Ar dating. Chemical Geology 145: 1-2 117152.

Richards JP and Noble SR (1998) Application of radiogenic isotope systems to the timing and origin of hydrothermal processes: Reviews in Economic Geology 10: 195-233.

Rollinson H (1995) Using geochemical data: evaluation, presentation, interpretation. In:Longman Group Limited editor 352 p.

Sato AM, Llambias EJ, Basei MAS and Castro C (2015) Three stage in the Late Paleozoic to Triassic magmatism of southwestern Gondwana, and the relationships with the volcanogenic events in coeval basins. Journal of South American Earth Sciences 63: 48-69

Taylor SR. and McLennan SM (1985) The continental crust: its composition and evolution. Blackwell, 312 p, Oxford. 
Thiéblemont $D$ and Tegyey M (1994) Unediscrimination geochimique des roches differencie estemoin de la diversited'origine et de la situation tectonique des magmas: Comptes Rendus del Academie des Sciences Paris 319: 2 87-94.

Sillitoe RH (1977) Permo-Carboniferous, upper Cretaceous and Miocene porphyry copper type mineralization in the Argentinian Andes. Scientific Communications, Economic Geology 72: 99-109.

Sillitoe RH and Perelló J (2005) Andean copper province: Tectonomagmatic settings, deposit types, metallogeny, exploration, and discovery. Economic Geology 100 Anniversary Volume: 845"890.
Williams WC and Madrid J (1999) El pórfiro cuprífero San Jorge, Mendoza. En: Recursos Minerales de la República Argentina. Editor, Zappettini EO. Instituto de Geología y Recursos Minerales SEGEMAR, Anales 35: 797-808, Buenos Aires.

Williams WC, Meissl E, Madrid J and Machuca BC (1999) The San Jorge porphyry copper deposit, Mendoza, Argentina: a combination of orthomagmatic and hydrothermal mineralization. Ore Geology Reviews 14: 185-201. 